St. Norbert College

Digital Commons @ St. Norbert College

Faculty Creative and Scholarly Works

$1-2021$

The role of information systems and knowledge codification for service provision strategies

John N. Walsh

Jamie O'Brien

Follow this and additional works at: https://digitalcommons.snc.edu/faculty_staff_works

Part of the Business Commons 


\section{THE ROLE OF INFORMATION SYSTEMS AND KNOWLEDGE CODIFICATION FOR SERVICE PROVISION STRATEGIES}

This is the final author manuscript.

The citation for this article is:

Walsh J.N. and J. O'Brien. (2021) "The Role of Information Systems and Knowledge Codification for Service Provision Strategies", Journal of Service Theory \& Practice, IN PRESS, https://doi.org/10.1108/JSTP-06-2020-0138 


\title{
THE ROLE OF INFORMATION SYSTEMS AND KNOWLEDGE CODIFICATION FOR SERVICE PROVISION STRATEGIES
}

\begin{abstract}
:
Purpose: While service scholars see modularisation as balancing the efficiency of standardisation with the value added through customisation the relationships between these concepts are under-theorised. In addition, although information and communication technologies can facilitate all three service strategies, the degree to which they codify service knowledge is not explicitly considered in the extant literature. The purpose of this paper is to develop and validate a model that examines service strategy trajectories by specifically considering the ICTs used and the degree of knowledge codification employed.
\end{abstract}

Design/Methodology/Approach: This study draws on three qualitative case studies of service departments of firms involved in cardiovascular applications, orthopaedic, spinal and neuroscience product development and information technology support. Data collection involved semi-structured interviews, document analysis and non-participant observation.

Findings: Findings show that ICTs were increasingly used to codify both standardised and customised services, though in different ways. For standardised services ICTs codified the service process, making them even more rigid. Due to the dynamic nature of customised services, drawing on experts' tacit knowledge, ICTs codified the possessors of knowledge rather than the service process they undertook. This study also identified a duality between the tacit development of customised services and modular service codification.

Originality/Value: The papers main contribution is the development of a model that integrates the literature on service strategies with knowledge management strategies to classify service standardisation, customisation and modularisation in terms of both service orientation and degree of ICT codification.

Research Limitations/Implications: The model is validated using case studies from three companies in the medical and information technology sectors limiting its generalisability.

Practical Implications: The importance of considering the degree of tacitness or explicitness of service knowledge is important for service codification. The paper provides managers with 
empirical examples of how ICTs are used to support all three strategies, allows them to identify their current position and indicates possible future trajectories.

\section{Introduction}

Service design and service innovation are receiving increased research attention given their centrality in advancing research and practice (Patricio et al., 2018). As interest in service innovation increases more attention is paid to leveraging service design as a research priority (Ostrom et al., 2015). Although both are intertwined (Antons and Breidbach, 2018) they are not alternative terms (Kurtmollaiev et al., 2018). Service design is seen as paramount (Storey and Larbig, 2018), key (Teixeira et al., 2019), able to foster (Joly et al., 2019), enable (Vink et al., 2019) and improve (Yang and Sung, 2016) service innovation. Service design is a service innovation approach (Mahr et al., 2013, Ostrom et al., 2010, Teixeira et al., 2017, Patricio et al., 2018, Yu and Sangiorgi, 2018, Meroni and Sangiorgi, 2011) that is concerned with the systematic application of design principles and methodology so as to develop services while, as (Gustafsson et al., 2020) argue service innovation is focused on the output rather than how it was realized. As firms start to use modular service strategies in designing new services (Cheng and Shiu, 2016) there are calls for more research on modularity as a way to advance service design. There has been a growing interest in how modularity can benefit service implementation (Bask et al., 2011) though the concept of modularity in a service context requires more research (Rahikka et al., 2011) and refinement (Blok et al. 2013). In addition, little is known about how technology can be leveraged so as to use service design for service innovation (Patricio et al., 2018).

ICTs support the service strategies of standardisation (Rust and Miu, 2006, Sundbo, 1994), customisation (Rust and Huang, 2014, Poulis et al., 2013) and especially modularisation (Sundbo, 2002). Although frameworks have been developed that consider modular strategies (Carlborg and Kindstrom, 2014) digital service modularity (Rajahonka et al., 2011) and combining service modularity with customisation (Bask et al., 2011) there is no research that focuses on how service knowledge is codified, and how ICTs interact with the dynamic nature of knowledge in organisations and the ongoing interactions between tacit and explicit knowledge (Venkitachalam and Busch, 2012). Indeed, within the knowledge management literature, Venkitachalam and Willmott (2013) argue that knowledge dynamism incorporates 
the continual reformulation of codified and tacit knowledge as they are continually being aligned to the organisation's competitive environment.

The purpose of this paper is to examine the trajectories through which firms leverage ICTs in support of their service strategies. In particular, the study examines how service knowledge is codified by ICTs and how such codification can change over time as firms move towards modularisation. To achieve this, we develop and validate the first model that theorises the relationship between standardisation, customisation and modularisation using an ICT-related dimension. The article is structured as follows. The literature section begins by outlining service design methods and then service strategies. Service design is multidisciplinary. In order to integrate ICTs and service strategies we draw on research into knowledge management strategies and the role of knowledge codification: this literature provides additional design practices, tools and methodologies that were used to develop a framework in the next section, which was validated using data from three case studies. The final section discusses the implications of the model on how ICTs can be used to support and leverage service strategies and draws conclusions.

\section{Literature Review}

Service Design

Service design gives life to new ideas (Teixeira et al., 2019, Ostrom et al., 2010) being identified as a service research priority (Ostrom et al., 2010, Ostrom et al., 2015). It is a humancentred, holistic and iterative approach to creating new services or improving current services (Blomkvist et al., 2010, Meroni and Sangiorgi, 2011, Mahr et al., 2013, Yu and Sangiorgi, 2018, Teixeira et al., 2017, Storey and Larbig, 2018, Patricio et al., 2018). Taking a holistic approach, service design involves coordinating people, the physical environment and the service delivery process (Magner, 2009). In addition, Teixeira et al. (2012) modelled the service context, activities, tasks or collections of actions used for a particular purpose, and non-human system actors as key elements. Service design is multidisciplinary (Teixeira et al., 2019, Furrer et al., 2016, Kurtmollaiev et al., 2018, Patricio et al., 2018, Antons and Breidbach, 2018), 'juxtaposing disciplinary contributions' with theory being borrowed from other disciplines to develop knowledge (Joly et al., 2019). It spans 
disciplines (Antons and Breidbach, 2018) such as management (Gupta et al., 2016) marketing (Pullman et al., 2001) and information systems research (Glushko and Tabas, 2009). Service design also involves perspectives such as customer experience (Andreassen et al., 2016) as well as how service design can create new operations and the use of technology that supports service delivery (Sampson, 2012, Glushko, 2010). Design practices are seen as existing between the macro-level of organizational capabilities and the micro-level of individual action (Karpen et al., 2017) and are capable of changing organizational routines and organizational mindsets (Kurtmollaiev et al., 2018).

Service design has changed organizational routines regarding co-production (Furrer et al., 2016) and codesign with customers (Trischler et al., 2018), providing guidelines on co-design activities (Dietrich et al., 2017). Customers are central to the process of service design (Trischler et al., 2018). Service design can affect customer interactions and experience by increasing reliability, responsiveness and assurance (Andreassen et al., 2016)). When examining customers' detection of scripts being used in service encounters (Victorino et al., 2012) argue that managers need to consider the effect of script detection on customers' perceptions of the service experience as script design is an important aspect of service design. Service design originated from service delivery through blueprinting (Shostack, 1984) service blueprinting (Bitner et al., 2008) and customer journey mapping (Folstad and Kvale, 2018). It has been used to maximise customer satisfaction by analysing routines involving the sequencing and timing of customer encounters. Zomerdijk and Voss (2010) found that service design was useful in designing customer journeys, sensory design, touchpoints and to design a 'dramatic structure' into customer experiences while Gupta et al. (2016) found that short experiences should lead to a 'crescendo' with longer encounters needing higher service levels at the start and end of the encounter. Design science research has also been used to examine trajectory touchpoints as a way of getting participants to discuss service experiences and identify potential touchpoints to design and develop artefacts (Sudbury-Riley et al., 2020). Service design can also affect organizational mindsets as customer journeys are mapped, storyboards deployed and walkthroughs followed, resulting in the creation of new job profiles such as digital customer journey analyst (Kurtmollaiev et al., 2018). A consequence of service design reshaping of employees' mental models is to enable them to perceive alternatives, by changing perceptions and how situations are framed, thus allowing service designers and service managers to create the conditions for employees to becomes more innovative (Vink et al., 2019). The mental models of designers of new healthcare practices were also found to be 
affected with service design allowing them to experience different contexts and explore new possibilities and provided the possibility for both repetition and continual change in how work was performed (Vink et al., 2019). Human aspects of service design include assimilating external customer knowledge through customer involvement (Storey and Larbig, 2018) with external knowledge from customers and internal knowledge to develop ideas into concepts (Trischler et al., 2018) through co-design (Dietrich et al., 2017). (Karpen et al., 2017) argues that little research exists into the organizational conditions that help service design provide valuable customer experiences. Similarly, Kurtmollaiev et al. (2018) argues there is a lack of research on how service design in organisations affects organisational logics. While Andreassen et al. (2016) examined how service design facilitates organisational change, their focus was on how IT's were used to design touchpoints rather than affect the design of the service strategy.

While holistic service design combines different areas of expertise, these are integrated using 'design based approaches, methods and tools' (Patricio and Fisk, 2013). One aspect is the development of new service design dedicated methods and models used to create new services (Teixeira et al., 2019). Research on service design has also considered the design and development of a method to map value networks (Patricio et al., 2018) and to develop an artefact to solve a class of problems (Teixeira et al., 2019). Teixeira et al. (2012) used service deign to examine customer experience: they saw the customer as surrounded by a context that involved other actors, artifacts and a technology enabled set-top box system (involving hardware and software) that interacted with the customer. Underpinning service design is a systems challenge on the design of the service system which configures people technologies and resources (Maglio and Spohrer, 2008). Bantau and Rayburn (2016) argue that service design is evolving from being static to becoming more iterative which, coupled with advanced information technology, will enable organizations to develop more personalized services. Historically the overlap between service design and service innovation centred on a system for design (Gustafsson et al., 2020). Design science can be applied to service design when considering the development of artefacts which include 'new service design methods' and leverage technology by providing a step-by-step approach (Teixeira et al., 2019). One of the six core areas identified by Joly et al. (2019) as contributing to service design was information systems. Lim et al. (2018) examined service design projects that used data sets to design new services, recommending making data collection from customers enjoyable and considering 
regulatory and privacy issues while Bantau and Rayburn (2016) examined the use of information technology at the front-end of service design as previously the focus was on the application of information technologies to services. Akesson and Edvardsson (2008) identified the dimensions of service design change as a result of implementing e-government, finding ICTs helped improve efficiency by enabling customer self-service and facilitating faster communication. Given the complexity of service design designing service solutions needs to include consideration of how technology itself is designed (Karpen et al., 2017). (Akesson and Edvardsson, 2008) argue that services need to be redesigned in order to achieve the benefits of information technology. Ostrom et al. (2010) call for a service science approach which they identify as involving the leveraging of technology as a central part. As argued by (Patricio et al., 2018) although new opportunities are created through technological changes there is little known about how to leverage technology in order to use service design to innovate services. As firms begin to design new services using modular approaches research on service modularity has begun to emerge (Cheng and Shiu, 2016) with modularity being viewed as a natural extension to design principle of services (Avlonitis and Hsuan, 2017). Over the past number of years (Frandsen, 2017) review of the modularity literature finds the application of modularity to service design in increasing. However, there is a need for still more research on modularization so as to advance service design (Avlonitis and Hsuan,2017).

\section{Service Strategies}

Service processes can be designed as dynamic and flexible or, as argued by Ostrom et al. (2010), they can be rigid and standardized. Firms can focus on customisation (Nordin et al., 2011) value being predicated on providing customised services (Muller and Doloreux, 2008, Bettiol et al., 2012) by matching their service to client's demands (denHertog, 2000). This is particularly important as customer needs become ever more divergent (Bask et al., 2011). Customized services come about as a result of high levels of interaction with clients products (Vence and Trigo, 2009) or, looked at from another viewpoint, the provision of highly customised solutions requires providers have a better understanding of their customers which facilitates the development of closer relationships (Nordin et al., 2011). Service value can be co-created (Edvardsson et al., 2005, Andreu et al., 2010, Shaw et al., 2011) through an interactive process between client and service provider (Gronroos, 2011) or, alternatively, through the interaction of client and supplier processes (Payne et al., 2008, Carlborg and 
Kindstrom, 2014). A downside being higher costs due to dedicated resources, customer specific knowledge, and continually adjusting the service offering in line with changes in the needs and situation (Johnson and Selnes, 2004).

Alternatively, rather than dedicating resources to a single client, firms can share resources across multiple clients (Cabigiosu et al., 2015). This enables efficiency in service deployment achieved by standardising service processes (Bottcher and Klinger, 2011, Davis et al., 2007, Sundbo, 2002, Tuunanen and Cassab, 2011). Service providers exploit their existing knowledge by standardising services for customers not interested in customisation or interaction (Sundbo, 2002). Standardisation also requires investment in ICT's to exploit service replication (Bettiol et al., 2012). Codification using ICT's increases service transferability (Olivia and Kallenberg, 2003) and reduces the need to produce knowledge with customers (Bettiol et al., 2012). Therefore, firms have a choice between standardisation and customisation when providing services, each having its own relative advantages and disadvantages. Sundbo (2002) posits that service firms are 'caught in a squeeze' between customization and standardization. This becomes increasingly difficult as customer needs become more diversified and heterogeneous (Bask et al., 2011).

A number of researchers have argued that a balance (Nordin et al., 2011, Olivia and Kallenberg, 2003) or compromise (Nordin et al., 2011) needs to be struck between these two alternatives through the use of modularisation (Rahikka et al., 2011, Araujo and Spring, 2010, Meyer and DeTore, 2001, Miozzo and Grimshaw, 2005). The idea of balance is used because customisation and standardisation are not seen as alternatives but rather poles along a continuum with modularisation occupying a middle position for service firms (Sundbo, 2002). Modularization can be used to reduce conflict between standardization and mass customization by providing standardized modules that can be combined to provide customization (Bottcher and Klinger, 2011). As such, modularity is an enabler (Pohjosenpera et al., 2019, Voss and Hsuan, 2009) and key element in achieving mass-customization (Pine, 1993, Duray et al., 2000). However, as argued by (Peters et al., 2018) modularity has extended beyond mass customization. When examining service modularity frameworks (Bask et al., 2011) posits the need to include additional alternatives to mass customization, while research on masscustomizers (Duray et al., 2000, Duray, 2002) identified 'modularizers' as only one of four 
types identified. Therefore, while service modularity has been closely associated with mass customization (Bask et al., 2011) argue that it is useful to consider the concepts separately to identify their particular domains.

Modularity has been defined as 'building a complex product or process from small subsystems that can be designed independently yet function together as a whole' (Baldwin and Clarke, 1997). It involves the decomposition (Gershenson et al., 2003) or subdivision (Heizer and Render, 2004) of a product into ultimately indivisible (Pekkarinen and Ulkuniemi, 2008) components that comprised of standardised sub-processes (Jacobs et al., 2007). These components are then easily replaced or interchanged (Heizer and Render, 2004) to provide a flexible system design (Davis et al., 2007) without any loss in functionality (Schilling, 2000). Cabigiosu et al. (2015) argue that the use of standard procedures are a constitutive element of modular services. A modular service is composed of one or more service modules (Pekkarinen and Ulkuniemi, 2008) which involves building on existing standardized service elements through the inclusion of customer specific value added elements (Pekkarinen and Ulkuniemi, 2008). Modularity can be used as a way of achieving the flexibility of customised offerings necessitated by increased client heterogeneity, while supporting the cost-efficiency associated with standardisation (Rahikka et al., 2011, Pekkarinen and Ulkuniemi, 2008, Schilling, 2000, Bask et al., 2010, Dorbecker and Bohmann, 2013). The development of modular systems, using reconfigurable components, allows service firms to exploit their knowledge about service processes across a number of supplier relations while spreading the costs of providing solutions over many customers (Cabigiosu et al., 2015, Davis et al., 2007).

Modularity provides the basis (Voss and Hsuan, 2009), for customization in a cost-effective manner (Bask et al., 2011). It is particularly related in the extant literature to mass customization (Voss and Hsuan, 2009, Pine, 1993, Bask et al., 2011, Duray et al., 2000) achieved through 'mixing and matching' (Voss and Hsuan, 2009) or bundling (Carlborg and Kindstrom, 2014) of components to create a service process. 'Information and communication technology is particularly suitable for flexibility and modulisation. It has a standardization logic in its algorithmic nature yet is flexible... The development of ICT may be supposed to be connected with development of modularisation in services, particularly knowledge services' (Sundbo, 2002:106). Given their suitability to facilitate modularisation we will next examine the role played by ICT's in standardising, customising and modularising services through knowledge management. 
Knowledge Management Strategies and the Role of Information Systems

Knowledge is a key requirement for services (Ekstedt et al., 1999, Gallouj and Weinstein, 1997) that are implemented through the application of specialised knowledge (Vargo and Lusch, 2008). While the existing literature identifies that information systems support service standardisation, customisation and modularity it does not examine the form that the knowledge takes as it is codified by, or flows through, these information systems.

ICTs facilitate customised services in several ways. They enable long-term individualised relationships with customers to be developed (Rust and Miu, 2006) and support deeper customer relationships (Rust and Huang, 2014). They provide opportunities to renovate services making them more personalised (Rust and Huang, 2014) facilitating social attachments that develop and enhance exchanges (Gremler and Gwinner, 2000) strengthening them over time (Adler and Kwon, 2002). In addition to building social contacts ICT's can also help identify constantly changing complex client needs (Pena et al., 2014, Poulis et al., 2013, San-Martin and Herrero, 2012). As production and consumption become less about objects and more about information and services the internet is the 'ultimate means for delivering services' enabling customisation by meeting customers' desires precisely, (Monnoyer, 2003).

Information systems also automate manual systems and standardise routines, improving efficiency by standardising and commodifying services (Rust and Huang, 2014). Service automation has been facilitated by information technology (Rust and Miu, 2006), leading to more self-service and moves to standardise services and create mass production (Sundbo, 1994). Interpersonal interaction during service encounters can be supplemented or replaced (Glushko and Nomorosa, 2013, Paluch, 2014). ICT's may be used to facilitate 'remote services' where technology is used to connect, access and modify service objects (Paluch and Blut, 2013, DuBay, 2009, Schumann et al., 2012, Ulaga and Reinartz, 2001) or as a substitute for service employees (Breidbach et al., 2012, Ostrom et al., 2015). 
While not the focus of their work, Bottcher and Klinger (2011) posit that there is a role for information systems in the management of service modules. Information technology and knowledge are seen as necessary internal resources for service modularity (Natti et al., 2017). While positing that appropriate data processing and systems were required for modularisation the examples of information systems detailed in their research relate to those used for service delivery such as remote monitoring and online ordering systems (Carlborg and Kindstrom, 2014). Information systems supporting services can be standardised or bespoke (Natti et al., 2017). Additionally, the services can take a modular form with standardised interfaces and components (Bardhan et al., 2010, Lorca and deAndres, 2011). While research has considered the effects wrought on service firms by information systems the various technologies can support all three service strategies.

In order to better understand of the linkages between service strategies and ICTs, it is necessary to consider how service knowledge is codified. Codifiability is the extent to which knowledge can be converted into an easily transferable form, e.g. by explicitly describing processes (Mithas and Whitaker, 2007). Information systems may support services by enhancing knowledge processes (Barrett et al., 2004) and enabling knowledge sharing (Leonardi, 2013, Carlo et al., 2012).

Knowledge is important for standardised, customised, and modular services. Codifying tacit knowledge provides an economic benefit through making knowledge reusable (Cowan et al., 2000, Gammelgaard and Ritter, 2005). It allows service providers to exploit high levels of knowledge replication through the use of standard codified services (Bettiol et al., 2012). The likelihood of improving efficiency through codification are reduced where 'bespoke service provision' exists (Bettiol et al., 2012) or where recurrence is unlikely (Sundbo, 1997). Muller and Doloreux (2008) find knowledge-intensive based service businesses derive a large proportion of their revenue from customised services. The provision of customised services requires customer-specific knowledge (Johnson and Selnes, 2004). One form of customised service provision identified by Bettiol et al. (2012) was the capability of a firm to be able to create novel solutions to client requirements, though they found that this necessitated firms to have engaged in effective knowledge development activities. 
From a modularity perspective, information systems provide the capability to both access and transfer process knowledge (Mithas and Whitaker, 2007). When examining service modularity, an explicit treatment of knowledge has been absent in some studies (Bask et al., 2010, Nordin et al., 2011, Dorbecker and Bohmann, 2013, deBlok et al., 2013) while other researchers have mentioned knowledge in that service firms are knowledge intensive (Pekkarinen and Ulkuniemi, 2008, Rahikka et al., 2011). Two knowledge management related capabilities which could be supported by service modularity identified by Ritala et al. (2013) involve the acquisition of knowledge about, and development of knowledge to support, customers. Natti et al. (2017) argue that modularity may be a way of supporting sharing knowledge relevant to service offerings going on to identify two key dimensions, the nature of modularity and nature of the underlying knowledge base, which can vary between normative (more tacit) and technical (more explicit) depending on professional service firms. They found that knowledge management and knowledge transfer were important in making a unique tacit knowledge into more explicit modules using information technology (Natti et al., 2017).

The best way to understand the concept of knowledge is to understand various types of knowledge (Spender, 1996). From the earliest works on knowledge management (Nonaka and Takeuchi, 1995, Davenport et al., 1996), a key distinction has been between tacit and explicit knowledge. Explicit knowledge is amenable to codification being declarative and objective (Jensen and Meckling, 1995, Zack, 1999) as well as impersonal and context independent, (Hislop, 2005). Conversely, tacit knowledge is dependent on specific contexts, being embedded in actions and experiences (Alavi and Leidner, 2001). It involves cognitive skills, mental constructs and frameworks (Hedlund, 1994), and may be a state of mind, (Alavi and Leidner, 2001) existing as individuals' experiences and interpretations (Sorensen and Kakihara, 2002, Leonard and Sensiper, 1998). These features make it difficult to share as it becomes 'embedded' or 'encultured' within individuals (Stankeviciute, 2001, Nonaka and Takeuchi, 1995). The tacit-explicit distinction is central to what has been called the 'most influential and highly referenced' research on strategic knowledge management (Venkitachalam and Willmott, 2013) namely the paper by Hansen et al. (1999) in which they consider two different orientations that knowledge management strategies can take: codification and personalisation. This paper argues that a parallel exists between the knowledge 
management and service literatures and contends that codification is appropriate for standardisation and personalisation for customisation.

The codification strategy involves tacit knowledge being extracted from individuals and its codification within in information systems, such as knowledge repositories, making it available for dissemination to other organisational members (Hansen et al., 1999). The codification strategy is predicated on knowledge reuse (Kumar and Ganesh, 2011) where there is investment in an initial codification of knowledge that saves time and costs when used repeatedly (Hansen et al., 1999). This strategy is appropriate where service delivery involves similar recurrent problems (Mukherji, 2005) and for service firms in mature environments where the services provided are stable over time and involved well-defined operational issues (Kankanhalli et al., 2003) that can be resolved with little recourse to tacit knowledge (Gorovaia and Windsperger, 2013). However, as Mukherji (2005) argues, where tacit knowledge becomes quickly obsolete it is not economic to codify it and so the personalised strategy may be preferred. In addition, the costs of employee turnover could be mitigated as codified knowledge remains after employees leave (Haesli and Boxall, 2005).

The personalisation strategy is more appropriate where there is high knowledge tacitness (Kankanhalli et al., 2003) such as situations involving creativity and innovation (Kumar and Ganesh, 2011). Personalisation seeks to take advantage of expertise, focusing on interpersonal conversations to develop deeper insights into problems, using information systems to connect people and develop networks, connecting experts who can exchange knowledge (Hansen et al., 1999). The underlying economic model relies on developing customised solutions to unique problems (Hansen et al., 1999). This makes it suitable where service firms are operating in a highly volatile environment where the service needs to be tailored to clients' unique requirements (Kankanhalli et al., 2003, Mukherji, 2005). The personalisation strategy was found to enable faster development cycles (Haesli and Boxall, 2005) as is particularly suited to work units that are highly networked in an organisation (Song et al., 2008). However, a disadvantage of the personalisation strategy was that tacit knowledge is lost when employees retire (Haesli and Boxall, 2005). 
While agreeing that Hansen et al. (1999) is a seminal paper Venkitachalam and Willmott (2013) go on to argue that it presents a static position that lacks a knowledge dynamics perspective which incorporates the continual reformulation of codified and tacit knowledge as they are continually being aligned to the organisation's competitive environment. Similarly, Venkitachalam and Busch (2012) argue that the position of Hansen et al. (1999) needs development in order appreciate ongoing interactions between tacit and explicit knowledge. Some knowledge management researchers include a temporal dimension in their models that examines how the knowledge form, either tacit or explicit, changes over t ime (Nonaka and Takeuchi, 1995, Boisot, 1998). However, as argued by Jimes and Lucardie (2003) and Walsh (2014), while some tacit knowledge is amenable to codification, some is not. Therefore, it is important that managers understand the degree to which organisational knowledge can be structured (Venkitachalam and Willmott, 2017). The original article by Hansen et al. (1999) proposed a static optimal 80:20 position between Codification and Personalisation strategies requiring one strategy to be dominant. More recent research has found the strategies complementing each other with neither predominant (Mukherji, 2005) and highly correlated, suggesting a mutually reinforcing relationship (Kumar and Ganesh, 2011, Walsh and Lannon, In Press). Such findings have led researchers to question the 80:20 split, instead arguing that the two strategies have a symbiotic relationship, each receiving benefit from the other, neither being predominant (Venkitachalam and Willmott, 2013, Jaismuddin et al., 2005) and that to take a more dynamics perspective allows both strategies to be enhanced (Scheepers et al., 2004). Scheepers et al. (2004) redefinition of Hansen et al. (1999) involved using a temporal perspective, leading them to argue that although initially an organisation may begin with a dominant strategy they will, over time, develop to a balanced position.

\section{Model Development}

Service design is 'betterment-orientated' and transformative (Karpen et al., 2017). An objective of service design is to create new, and improve current, services (Blomkvist et al., 2010, Meroni and Sangiorgi, 2011, Mahr et al., 2013, Yu and Sangiorgi, 2018, Teixeira et al., 2017, Storey and Larbig, 2018, Patricio et al., 2018). This may occur within firms following a standardization (Muller and Doloreux, 2008, Bettiol et al., 2012), customization, (Cabigiosu et al., 2015) or more recently, modularization strategy (Rahikka et al., 2011, Araujo and Spring, 2010, Meyer and DeTore, 2001, Miozzo and Grimshaw, 2005). Previous models in the service 
literature have presented a continuum from pure standardisation, through mass customisation to pure customisation (Lampel and Mintzberg, 1996, Pekkarinen and Ulkuniemi, 2008). However, the Lampel and Mintzberg (1996) typology was developed for a production rather than a service perspective. Those models with a service focus typically use two dimensions (Duray, 2002, Carlborg and Kindstrom, 2014, Sundbo, 2002, Bask et al., 2011). They either classify standardisation, modularity and customisation (Sundbo, 2002) or use one (Duray, 2002) or two (Bask et al., 2011) of the concepts as dimensions. Other dimensions used in service models have been: customer focused such as the point at which customer involvement took place (Duray, 2002), whether the customer was active or passive (Carlborg and Kindstrom, 2014), service process focused, whether they were rigid or fluid (Carlborg and Kindstrom, 2014), or at a higher, firm level, whether the firm's orientation was identified as having low or high dynamism, (Sundbo, 2002).

As discussed in the previous section existing studies have identified that service process codification using ICTs can support either standardisation or customisation (Sundbo, 1994, Monnoyer, 2003, Rust and Miu, 2006, Rust and Huang, 2014) which are being squeezed (Sundbo, 2002) in response to customer needs and cost-efficiency. All three service strategies are supported by ICTs and knowledge management strategies (Hansen et al., 1999) which can dynamically change (Scheepers et al., 2004, Venkitachalam and Willmott, 2013, Walsh and Lannon, In Press). Consequently, as the literature indicated that the underlying service strategy also changes, to achieve a balance between standarisation and customization through modularity (Nordin et al., 2011, Olivia and Kallenberg, 2003, Sundbo, 2002) design principles from knowledge management strategies can be usefully drawn upon and integrated into service design.

The purpose of this research is to develop and validate the first model to explicitly introduce an ICT-related dimension when theorising the relationship between standardisation, customisation and modularisation. The model's ICT dimension focuses on the degree of codification present, distinguishing between tacit and explicit knowledge. It draws on knowledge management design principles by moving from an initial position where tacit service knowledge is created by employees (Nonaka and Takeuchi, 1995, Nonaka, 2007) through increasing levels of codification facilitated by ICTs. The degree of codification, though presented in the model as high or low, is not dichotomous, with varying degrees of 
codification possible. Like (Bask et al., 2011) we believe that this delineation enables more extreme cases to be described and facilitates the visualisation of different firm trajectories. Similarly, for our service dimension, we chose a dichotomous service orientation using the Carlborg and Kindstrom's (2014) categorisation of services as either rigid and dynamic, representing the distinction between standardisation and customisation. Based on the extant literature from both services and knowledge management research we propose a framework that categorises the concepts of standardisation, customisation and modularisation along dimensions of ICT codification and service process orientation (see Figure 1). This framework can be used to identify how firms use ICTs to develop their service offering over time.

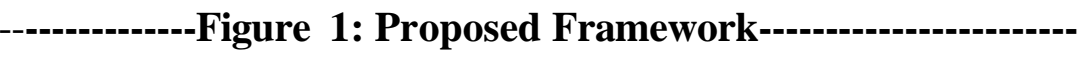

\section{Research propositions}

Previous service deign research has considered blueprinting (Shostack, 1984, Bitner et al., 2008) and mapping service encounters over time (Zomerdijk and Voss, 2010, Gupta et al., 2016). As the designs of KM strategies are increasingly being viewed in dynamic rather than static terms (Venkitachalam and Willmott, 2013, Venkitachalam and Busch, 2012, Scheepers et al., 2004, Walsh and Lannon, In Press) our propositions examine potential trajectories for service firms over time. The codifiability of knowledge changes over time (Nonaka and Takeuchi, 1995, Boisot, 1998) and ICTs are designed to codify knowledge in different forms (Hansen et al., 1999) and manage the transition between those forms (Scheepers et al., 2004). Rather than using service design to develop co-design guidelines (Dietrich et al., 2017) this study examines moves between ICTs designed to support different purposes.

Codification of tacit knowledge using ICTs provide economic benefits through knowledge reuse (Cowan and Foray, 2000, Gammelgaard and Ritter, 2005) enabling the replication of standard codified services (Bettiol et al., 2012) and the standardisation of routines (Rust and Huang, 2014).

Proposition 1: Though initially tacit, knowledge about standardised services will become increasingly codified and rigid through the use of ICTs.

ICTs may enable more personalised services (Rust and Miu, 2006, Rust and Huang, 2014) thus strengthening social contacts (Adler and Kwon, 2002). 
Proposition 2: Though initially tacit, knowledge about customised services will become codified, to a low extent, through the use of non-modular ICTs.

Propositions 1 and 2 indicate a move from service design based primarily on the knowledge of experts to an increasing reliance on ICT's designed to codify service process, and map and facilitate relationships respectively (Hansen et al., 1999, Scheepers et al., 2004).

Modularity can support customisation (Rahikka et al., 2011, Pekkarinen and Ulkuniemi, 2008, Schilling, 2000, Bask et al., 2010, Dorbecker and Bohmann, 2013). ICTs can be used to deliver services that meet customers' needs more precisely (Monnoyer, 2003). Creating new knowledge begins at a tacit level (Nonaka and Takeuchi, 1995). A modular service needs one or multiple service modules (Pekkarinen and Ulkuniemi, 2008) that can be 'mixed and matched' (Voss and Hsuan, 2009) or bundled (Carlborg and Kindstrom, 2014). Therefore, we posit that there are two mutually reinforcing activities: drawing on modules to create a new service and developing new modules as part creating new services.

Proposition 3a: Components of existing services, codified in modular ICTs, can be reused when creating new customised services.

Proposition 3b: Though initially tacit, knowledge about customised services will become highly codified through the use of modular ICTs.

Propositions $3 \mathrm{a}$ and $3 \mathrm{~b}$ suggest the use of ICTs, designed to codify service knowledge in a modular way, which can provide employees with reusable components designed to be integrated (Voss and Hsuan, 2009, Sundbo, 2002, Ritala et al., 2013).

While standard systems provide efficiency, firms may seek to move towards modularisation to balance this with some degree of flexibility (Nordin et al., 2011, Olivia and Kallenberg, 2003).

Proposition 4: Highly codified rigid standardised services become more dynamic and customised through the use of modular ICTs.

Proposition 4 indicates that firms will seek to change the underlying design of their system from one which codifies knowledge in rigid standard ways to one that possesses a modular design. 
These four propositions can be incorporated into our model as outlined in Figure 2 below.

Figure 2: Framework Propositions

Having developed a model and related propositions this study now seeks to test and validate these using three case studies.

\section{Research Methodology}

A case research methodology (Yin, 2002) was chosen as the phenomena was to be examined in its natural context (Darke et al., 1998) and where clarification rather than measurement was sought (Riege and O'Keeffe, 2007) regarding the nature of standardisation, customisation, modularity, and their interaction with technology over time. Case studies are widely used to examine service delivery strategies (Nordin et al., 2011, Heikka et al., 2018, Pohjosenpera et al., 2019), with exploratory case studies for service modularity at an early stage of development (Carlborg and Kindstrom, 2014). Appropriate when examining human action and interpretations around using information systems (Walsham, 1995) cases have been used to explore knowledge codification and dissemination (Hazlett et al.,2008).

Primarily used for theory building (Barratt et al., 2011, Piekkari et al., 2009) case studies are also used for theory testing (Iacono et al., 2011) using previously articulated propositions (Lokke and Sorensen, 2014) which may be validated or refuted (Sarker and Lee, 2003). This makes the case 'of secondary interest, it plays a supportive role, and it facilitates our understanding' (Stake, 2000:437). Like other service-focused studies (Tuominen and Martinsuo, 2019; Pohjosenperä et al., 2019; De Blok et al., 2013), this study used cases to test a theoretical model's propositions. This has been achieved using 2 sub-cases possessing different characteristics (Pekkarinen and Ulkuniemi, 2008). Like (Nordin et al., 2011) we sought to validate propositions by identifying and examining material that supported the propositions as well as considering material which was incongruous and might result in a need for alternative propositions. Additionally, such testing is employed where multiple literatures 
have been integrated into a framework (Turner et al., 2014, Nissen, 1999) to identify framework elements more specifically (Krull et al., 2012), to gain more insights into a framework (Qui and Lui, 2014), as well as providing a 'concrete illustration' of the application of a framework (Pan and Scarbrough, 1999).

\section{Research Sites}

As this is part of a wider study, in line with previous work, multiple cases were chosen to improve theoretical understanding, methodological rigour (Yin, 2002, Eisenhardt, 1989), augment external validity (Barratt et al., 2011), and improve theoretical understanding when exploring varied settings (De Blok, et al. 2013). Case companies were selected based on several criteria. (Silander et al., 2017) chose polar or contrasting cases todiscover pertinent conditions in different circumstances. Similarly, (Heikka et al., 2018) chose extreme project examples to enable a deeper analysis while (Pohjosenpera et al., 2019) examined multiple case studies of four different kinds of hospitals to examine modularity in each. This study chose three contrasting cases of companies involved in each of the three service strategies being investigated (Table 1). In addition, as the propositions being tested involved the role of knowledge and ICTs, the companies' services examined were knowledge-intensive and reliant on the use of information technology. Case companies were selected which were involved in knowledge-intensive service based work, ICTs were employed to support such work and each case initially engaged in a different service strategy.

\section{---Table 1: Summary of Cases Selected ---}

Co. A was a global leader in the supply of metal shafts for cardiovascular applications. It worked closely with clients when designing products such as stent delivery systems, catheters and biopsy devices. While serving clients involved tacit knowledge exchange during extensive discussion of alternative ideas, requirements for new product development and supply-chain logistics as well as providing solutions to subsequent issues, Co. A. operated in a highly regulated medical environment. There was a need for efficiency through service standardisation with the company seeking to use ICT to increase codification. The ICT implemented was called User Productivity Kit (UPK). This system codified tacit knowledge and captured problems, processes, located solutions, and documented these centrally. This enabled reuse of these standard solutions over time for the solving of client problems. 
Co. B was a pioneer in the fields of orthopaedics, spinal care, and neuroscience therapies. This study focused on customised services provided by the companies Innovation Centre and to other internal departments of the organisation such as advanced manufacturing and the global supply chain group. as the company grew, Co. B wanted to identify experts more efficiently while maintaining their reputation for using experts' tacit knowledge to customisation solutions. This prompted them to implements 'Talent Navigator' and 'Link' ICTs to enable them search for specific experts. In addition, they explored the need for standardisation through another system called 'Agile'.

Co. $\mathrm{C}$ is billion-dollar corporation providing hardware and software as well as support to large corporate customers. The services Co. C provided involved monitoring, identifying and resolving instances where clients had problems with its products. The work involved resolving knowledge intensive and highly technical hardware and software problems in unique client configurations. To company was heavily reliant on the use of a modular knowledge management repository that categorized and stored service context and associated procedures to be followed.

\section{Data Collection and Analysis}

Multiple methods were utilised to collect data on the interactions of the technologies being used and service provision, similar to a studies by Luijkx et al. (2014) and (Heikka et al., 2018). These included: observation, semi-structured interviews as well as through corporate documents and access to corporate ICTs. Pilot interviews and access to organisational documents provided a context to develop a set of questions and probes for the interviews. All 59 interviews were recorded and transcribed. Each interview lasted between thirty and ninety minutes. To obtain further information, document analysis and non-participant observation was then administered. The use of multiple data collection methods, like those used by Heikka et al. (2018), allowed for triangulation across the individual interview findings and aggregate observation findings.

In this study, we used stratified purposeful sampling as described by Patton (2014), in conjunction with snowball sampling as used by Tuominen and Martinsuo (2019). A sample of 
employees across all levels (managers, shift leaders, knowledge workers, and novice participants) provided viewpoints across the three case sites (Table 2). Interviewing multiple respondents allowed us to examine issues both in breadth and depth (Brown, 1999, Luijkx et al., 2014). Similar to the selection process (engagement of employees with the projects/processes under study) used by Tuominen and Martinsuo (2019), the interview participants were selected on the following criteria: their work involved direct knowledgeintensive service provision to clients, either internal or external or, for managers, they managed such workers; they used the relevant companies ICTs, identified above, as part of their work. Therefore, like (Carlborg \& Kindström, 2014) interviewees were the primary architects of the ICT implementations, worked with and used the technologies being studied, and were familiar with service delivery.

\section{---Table 2: Participant Selection ---}

Interview data was analysed, both as one of a number of sources (Nordin et al., 2011, Pekkarinen and Ulkuniemi, 2008) or as the primary source of data (Heikka et al., 2018, Carlborg and Kindstrom, 2014, Cabigiosu et al., 2015, Kowalkowski and Brehmer, 2008, Rahikka et al., 2011, Silander et al., 2017) (Silander et al., 2017) in service modularity research. Each interview began by discussing service activities and how ICTs were used to support this work. The data on specific service technologies, and issues respondents were elicited via open-ended questions: the interviewees were asked to identify issues they faced during implementation of the technologies and the trajectory of service provision.

Following interviews, a list of specific issues and areas of overlap between cases was developed. This list provided the content for observation and document analysis. Huberman and Miles (2002) method for data analysis was used, incorporating the interdependent processes of data collection, data reduction and data display and conclusion drawing and verification. The steps of data reduction and data display were aided significantly using NVIVO qualitative data analysis software. Observational notes and documentation analysis were used to enhance interpretation, check existing ideas and add more depth to findings. 
Studies validating service frameworks using case studies have coded data based a 'theoretical pre-understanding' of service modularity (Pekkarinen and Ulkuniemi, 2008) using elements and themes identified in their theoretical framework (Rahikka et al., 2011, Heikka et al., 2018) in order to identify similarities (Lokkegaard et al., 2016) and differences among different projects (Heikka et al., 2018) using within and then cross-case analysis (Silander et al., 2017). Each company was chosen as an exemplar of a service strategy and data was coded as relating to standardisation, customisation and modularity. Both service and knowledge management literatures were the primary sources for our theoretical pre-understanding. The elements and themes used were the degree to which service knowledge was tacit in nature or was codified. In particular themes around changes, and associated rationales, in the ICTs used to support changes along with challenges encountered. This enables propositions to be tested. After coding, analysis involved identifying connections between elements present in the framework, like Rahikka et al. (2011) so that themes and patterns were developed that were extracted that were linked to the theoretical framework enabling the findings to be, similar to (Carlborg and Kindstrom, 2014), grounded in the theoretical framework and in empirical reality.

Similar to the data collection protocol used by De Blok et al. (2013), for the data analysis to evaluate the propositions of this paper, each company was classified by the authors into each service orientation using the framework in Figure 2, and then coded according to the type of service strategy (Standardisation, Customisation, Modularisation), along with the particular ICT used, as supported by the interview data. For example, Company A is a low-codification, rigid, standardiser; Company $\mathrm{B}$ is a high-codification, rigid standardiser, whereas Company $\mathrm{C}$ is a high-codification, dynamic, modulariser.

The above methods for this study were selected to satisfy the logical tests of construct validity, reliability, and external validity (Yin, 2002) and avoid previously identified methodological problems with case-based research (Benbasat et al., 1987, Brown and Duguid, 1998). More specifically, the constructs of interest were issues and experiences of organisational members use of ICTs to standardise, customise, modularise services or move between these approaches. Construct validity was achieved by the collection of data from multiple informants, and by the participant review of the researcher's case study reports. Reliability was achieved using the same case study protocol for all three case sites. Multiple data collection methods facilitated 
triangulation across interviews, documents and observations. External validity cannot be claimed with a three-case design; however, theoretical sampling was achieved because the three case sites were predicted to develop different levels of codification over time due to their maturity in the process, similar to (Tuominen and Martinsuo, 2019).

\section{Model Validation}

Data collected for the three case companies were examined against each of the propositions developed.

Proposition 1: Though initially tacit, knowledge about standardised services will become increasingly codified and rigid through the use of ICTs.

Co. A, a medical device company specialised in products for less invasive therapies such as Stent Delivery Systems, Catheters, and Biopsy Devices. Its design and development service enable other companies to bring these products to market. For this firm, knowledge was predominantly tacit, embedded in informal employee networks; 'it's not exactly a very good way of doing it because...it's just word of mouth' (Shift Lead) often held by short-term knowledge specialist. Sometimes, even when searching for explicit knowledge, particularly new employees, could not locate it. 'What would have tended to happen in the past is fix the problem, move on. It happens again, 'oh God, how do we do that?' And you go back to this whole running in circles thing. My attitude is why waste the energy doing that? If you fixed it once, record it, reuse it.' (Manager). Consequently, a lack of standardised knowledge was 'definitely a problem for us', (Experienced Knowledge Worker).

ICTs were implemented to provide service delivery quickly, to a consistent standard while reducing reliance on tacit knowledge. Consequently, Co. A standardised its knowledge through codification of service processes. 'They find it difficult to find out... who knows about [particular process] - Who's our guy?' (Manager). 'If you have a database full of solutions and people even know what kind of things you're looking for...they wouldn't even know where to begin to look right now' (Shift Lead). The goal was to use the deep pool of tacit subjectmatter expertise and create a standardised knowledge base that could be reused. 
The ICT was called 'User Productivity Kit' (UPK) see Figure 3. It began with the codification of tacit knowledge and captured problems, processes, located existing solutions, documenting these centrally to enable reuse of these standard solutions. This involved talking with subjectmatter experts (the 'blue jackets'), recording their step-by-step solutions to client problems.

'Whether it's UPK...or some sort of a centralised repository of knowledge, so that all of the people in that group can start looking into it and kind of start going, 'oh, so I was supposed to be doing it this way all the time'...I rarely ever come across a problem in here that there wasn't a very simple solution...it was just that whoever happened to be looking at it had absolutely no idea that such a thing ever existed.' (Manager)

\section{--- Figure 3: User Productivity Kit at Co. A. ----}

Standardised proceduresenabled services be provided quickly so that if a client had a particular problem with a Stent Delivery System, UPK could select a standard solution from the repository. Employees of Co. A used UPK to locate and reuse knowledge, some of which had been previously hidden, or lacked designated ownership. UPK led to increased client confidence in the services delivered to them. Indeed, for the sheer volume of process knowledge needed, one team lead remarked that UPK was extremely useful:

'Instead of me having the knowledge to transfer onto somebody else...for the volume of process knowledge that has to be transferred, you'd be talking about having an army of people delivering it.' (Team Lead)

For Co. A, its ICT improved knowledge reuse of standardised procedures and successfully developed systems to standardise specialists' knowledge. Many employees used these systems as a way of moving to a more standard approach to meeting client requirements. The use of ICT by Co. A, moving from tacit knowledge to more explicitly codified standardised rigid knowledge supports Proposition 1.

\section{----Figure 4: Codification of Standardised Services----}

Proposition 2: Though initially tacit, knowledge about customised services will become codified, to a low extent, through the use ofICTs. 
Like Co. A. most of Co. B's knowledge was also held tacitly by a few experts: 'There's a lot of tacit knowledge locally held and we find we have huge gaps when people go on holidays.' (Manager). The company had grown from a small core group of experts that relied on their tacit knowledge to develop customised client solutions. Longer-term employees had an advantage; 'I'm here seven years, so ... I know who's who' (Shift Lead). Much of the knowledge was learned from people through an informal interpersonal network with time wasted in locating expertise.

$60 \%$ of employees in the Innovation Centre were on short-term contracts for specialised tasks, after which, the expert left and 'that knowledge is gone' (Experienced Knowledge Worker). As one Shift Lead remarked; 'If ... my previous boss, had left in the morning and I took over, there was stuff there I just wouldn't have' (Shift Lead). Co. B wanted to be able to identify their experts more efficiently while maintaining their reputation for customisation. This prompted Co. B to begin codifying the location of their knowledge using 'Talent Navigator' (Figure 5) and 'Link' ICTs. Talent Navigator was a Web-based knowledge location tool that allowed employees to find specific experts through a mapping interface. 'Link' was a web-based system that acted as a social network, similar to LinkedIn. It was a 'kind of knowledge network, the kind of sharing ideas, people post things on there. If you say: 'I've got a problem with X, can anyone help?' (Experienced Knowledge Worker). It enabled communication between engineer and expert or between different departments. Co. B used Talent Navigator and Link to make explicit and categorise tacit knowledge, increase their expert visibility, and locate specialists possessing such tacit knowledge.

\section{----- Figure 5: Talent Navigator System -----}

These ICTs facilitated the location of experts possessing the tacit knowledge to customise service solutions, saving workers' time; 'It would save myself time, trying to track down whoever I could ask about that or will save them time as well' (Novice Knowledge Worker). Co. B was able to start to build a repository of categories of relevant expert knowledge. This provides validation for Proposition 2.

Consequently, they developed greater internal efficiency and greater customer credibility. In the next section we will discuss how, after Co. B deployed ICTs to locate expertise, it began to codify and standardise knowledge to offer more modularised customised solutions to the more complex client problems, using a new system 'Agile'. 


\section{-----Figure 6: Customised Knowledge Codification-----}

Proposition 3a: Components of existing services, codified in modular ICTs, can be reused when creating new customised services.

Proposition 3b: Though initially tacit, knowledge about customised services will become highly codified, through the use of modular ICTs.

At Co. B's Innovation Centre, after codifying the location of experts' tacit knowledge using Talent Navigator and Link, the company was still dependent on a small group of subject-matter experts for customisation. Employees might customise a new service without subsequently codifying the process. This provided the impetus for further modular knowledge codification through the 'Agile' system which would store and deploy, in various combinations, explicit knowledge and offer modular solutions. Co. B's eventual goal was to move toward a system that would have a repository of accurate modular solutions that would eventually solve problems without the need for a constant rotation of subject specialists. There was a move toward building with 'Lego blocks' allowing employees reuse existing bricks while applying their skills to construct something new.

As one manager stated: 'The huge area for focus for us ... is increasing the efficiency of our support staff... the need to get people understanding the importance of it. And then you got to get people capturing it, classifying it right, putting it up there. You got to get people using it, so that it becomes a part of your daily life.' (Manager). Agile sought to develop a set of solutions that were interchangeable, accompanied with detailed information such as key work steps, pictures of solutions, key points, and 'what might happen if key points are not followed'. Agile supported knowledge reuse in modular fashion (See Figure 7) but was in the early stages of development: 'We don't have a 'proper' system for knowledge sharing.' (Experienced Knowledge Worker).

\section{Figure 7: Agile System-----}

With the implementation of Agile came its own challenges. One manager argued: 'There's too much in there. There isn't enough classification of the data', whereas another engineer stated that 'the search functionality of it isn't great...they're talking about replacing it eventually'. Though the Agile system would be the primary way in which Co. B would approach modularisation, there were some early problems that needed to be solved: 'If you wanted to just randomly pull out the last five, ten, twenty protocols [solutions]... you'd have to be 
searching specific areas so you'd have to know what projects were gone through. It's not straightforward to get exactly what's there, especially for someone who's new' (Team Lead), however, most of these issues were functional in nature. In effect Co. B had, as shown in Table 3 below, begun to move along the trajectory indicated by proposition $3 \mathrm{~B}$ to become more modularised, and these initial challenges were to be expected, and as one engineer described, there was a great opportunity going forward: 'if it was easier to operate, it would probably mean that you might be more inclined to go in and say, 'oh yeah, let's have a look at this one', or 'let's have a look at how they did that', and this will happen over time.

\section{---Table 3: Co. B. Process Standardisation--- ----Figure 8: Codification of Customised Modular Knowledge ----}

The services provided by Co. C. involved problems arising from clients' implementation of both Co. C's and external vendors' products which gave rise to new and unique sets of client problems. Co. C. had a well-developed modular knowledge management systemcalled Primus. As problems were typically recurrent across the client base a key knowledge management objective for Co. C was to benefit from both economies of scale by reusing explicitly codified solutions and customisation by mixing and matching elements from existing solutions (called knowledge articles).

It engaged in what it termed 'Knowledge centred support'. It implemented this using an organisational repository the objectives of which, as outlined in an Internal Training Document were:

- Improve service levels to customers

- Gain operational efficiencies

- Call avoidance

- Increase Global Services' value to [Co. C.]

- Improved job satisfaction of Customer Service personnel

The repository 'is good for finding out if there actually are specific solutions for the problem... I think there's about 40,000 solutions you see' Experienced Service Engineer. 
A large proportion of knowledge regarding technical problems were codified using very structured solutions as outlined in Table 2. These included sections detailing the problem context in terms of taxonomies of errors, technical configurations and the service procedure, which could contain a number of action sets, to be followed in the 'Fix' section. The solutions were modular in form as contextual elements were defined by reusing existing categories, and service procedures were developed by drawing on existing standard sets of actions whenever possible.

'Solutions can be seen as "modular" in that each statement stands apart, and care must be taken in creating them.' Internal Training Document

'The base unit for storing information is the concept. A group of connected concepts forms a statement. A group of connected statements forms a solution' Internal Document

\section{---Table 4: Sections of a Modular Repository Solution---}

Given the modular nature of Co. C's repository, all tacitly developed solutions by employees, regardless of their complexity, were immediately codified explicitly in a modular format (proposition 3b).

'People had put in solutions, they saw a problem once and then they put in a solution there just in case it happened for someone else which was ideal' Shift Lead

The cause and effect of such problems were known to the extent that, once identified, the fix could be guaranteed to work without modification. Re-using existing solutions was supported by the structured nature of the knowledge management repository and standardised taxonomy of errors and client configurations.

'If you go putting in text it can throw anything back at you, you know but if you're putting in a specific errorcode it will take you there... it will actually bring you up the exact solution' Experienced Knowledge Worker

In more complex situations employees found that while no solution existed to a current problem, employees were often able to identify when parts of existing solution(s) could be applied to the current problem. This involved checking if a set of actions would work in a new 
context. It was possible for workers to recombine components (standard sets of actions) from a number of solutions (proposition 3a).

'You'd have 50\% alright you would yeah like a solution where you would find it alright... See a lot of the solutions would be for a certain [Problem type] you're above that [error]code then only half a solution would apply. ' Experienced Service Engineer.

When even this was not possible then employees could find that existing solutions gave them ideas on how to approach developing a new, customized, service.

'... it definitely gives you a head start. It will point you in the right direction and a lot of the solutions are written up anyway and have links to documentation in the interface and even sometimes looking at [Knowledge Management Solution Repository] will give you an idea and point you in a specific area.' TeamLead

\section{----Figure 9: Customisation-Modularisation Duality ----}

Proposition 4: Highly codified rigid standardised services become more dynamic and customised through the use of modular ICTs.

As discussed earlier, Co. A had created a standardised set of solutions using UPK. ' ...UPK was primarily bought for processes, but we were starting to use it for other things...' (Team Lead). Having developed codified solutions for standardised service delivery, the next goal was to become more modular.

Figure 10 presents an early view of the modularised approach. Unfortunately, they ran into several issues and this was not achieved.

\section{----Figure 10: Standardised to Modular Knowledge----}

A manager made the point that the original captured standarised solutions needed revision. The question arose as to how these original experts were recording or capturing this tacit knowledge: 'A lot of the cases - what we had was so-called experts, but we deemed them the people who are most knowledgeable. I'll take back the word expert. We would have the people who were most knowledgeable recording the instances.' (Manager) In the end, Co. A succeeded in standardising its tacit knowledge and creating a reliable repository of standardised solutions. As one engineer put it: 'It gives you the confidence in terms of 'I know now this is 
how to approach this and how to deal with it'.' (Engineer) It ultimately fell short of the final goal - complete modularisation, but who is to say they will not have more success with that in the future.

\section{---Table 5: Model Support---}

\section{Discussion and Conclusions}

There is a need to leverage service design as a research priority in service research (Ostrom et al., 2015) with little known about how to leverage technology for service design (Patricio et al., 2018), particularly when modularity is emerging (Cheng and Shiu, 2016) as a natural extension of service design (Avlonitis and Hsuan, 2017). In response, this paper set out to develop and validate a model for conceptualising organisational trajectories between service standardisation, customisation and modularisation strategies in the context of ICT's and knowledge codification. Service design involves coordinating multiple elements (Teixeira et al., 2012, Magner, 2009) including design methods, tools and models (Patricio and Fisk, 2013, Teixeira et al., 2019). By focusing specifically on the technological (ICT) element and service activities this paper extends service design research in general and service strategies in particular. While previous service design research has examined using data (Lim et al., 2018) and technology integrated within services (Teixeira et al., 2017) there is a need to consider how technology is designed for service solutions (Karpen et al., 2017). Service design is multidisciplinary (Teixeira et al., 2019, Furrer et al., 2016, Kurtmollaiev et al., 2018, Patricio et al., 2018, Antons and Breidbach, 2018) integrating theories from other domains (Joly et al., 2019). While the management discipline has been incorporated (Gupta et al., 2016) this paper adds the knowledge management discipline.

Services are knowledge intensive (Vargo and Lusch, 2008) with ICTs supporting standardisation (Rust and Huang, 2014) and customisation (Monnoyer, 2003) and moves towards modularization (Rahikka et al., 2011, Araujo and Spring, 2010, Meyer and DeTore, 2001, Miozzo and Grimshaw, 2005). KM strategies (Hansen et al., 1999) are usefully applied to a service context given the similarities between the codification strategy and service standardisation and personalisation and service customisation. The model developed in this paper integrates prior research on service strategies, knowledge management and ICTs and is the first study to explicitly incorporate ICTs and Knowledge as a dimension, deriving propositions that were tested at the firm-level. The theoretical developments in KM theory, 
moving from a static to a dynamic perspective (Scheepers et al., 2004, Venkitachalam and Willmott, 2013), and the similarity between KM and service strategies, with moves from standardisation to modularity and from customisation to modularity (Olivia and Kallenberg, 2003, Nordin et al., 2011), informed including propositions relating to potential trajectories useful. Prior studies have found sevices can be rigid and standardised in design (Ostrom et al., 2010) to provide efficiency (Davis et al., 2007, Bottcher and Klinger, 2011) with routines being standardised through ICTs (Rust and Huang 2014). These prior findings are supported by the current study (proposition 1). Co. A used the UPK information system to codify tacit knowledge to standardise entire service processes. This provided efficiency, increasing the consistency and speed of service delivery though it also increased process rigidity. The method through which service knowledge was codified, in detail, but as an entire process, increased efficiency when the entire service was subsequently reused. Though efficient, the lack of ICT support for modularity resulted in rigidity, when codified knowledge was partially amenable being reused in new contexts. This highlights the importance of considering how ICTs codify service knowledge, as codification without considering the ability to decompose and recombine elements can result in efficient rigidity.

The value derived from customised services (Muller and Doloreux, 2008, Bettiol et al., 2012) necessitates matching services (denHertog, 2000), to divergent (Bask et al., 2011)client needs. The role of ICTs in the development of customised services was examined (propositions 2, 3a, 3b). When customised services were relient on predominantly tacit knowledge, a first step (Co. B) was to codify not the process knowledge (as in Co. A) but to classify categories of knowledge, relating these to the experts who posessed them (proposition 2), necessitating a lesser degree of codification. This improved the efficiency, speed and consistency of expert location while retaining the subsequent flexibility of service customisation. Though previous research (Poulis et al., 2013, San-Martin and Herrero, 2012, Pena et al., 2014, Rust and Huang, 2014) has indicated ICTs can support customisation, this research, by examining the technology in more detail, identifies the importance of considering the degree of codification used as ICTs may be present butlimited.

Bespoke customisation reduces the efficiency achievable through standardisation (Bettiol et al., 2012). Standard procedures are part of modular services (Cabigiosu, Campagnola et al. 
2015). An examination of modular systems (Co. C) identified efficiency derived from the use of standardised reusable components that increased both efficiency and flexibility. This raises wider questions over the definition of customisation. In a modular context, with unique client needs, what is necessary to qualify as bespoke or customised? Must the resultant service be created $\mathrm{ab}$ initio or is it sufficient that existing standardised elements be reconfigured or bundled uniquely? We propose that customisation and modularisation can exist as a mutually reinforcing duality (propositions $3 \mathrm{a}, 3 \mathrm{~b}$ ) resulting in what could be termed 'modular customisation'.

Service design is a way of improving current services and creating new services. (Blomkvist et al., 2010, Meroni and Sangiorgi, 2011, Mahr et al., 2013, Yu and Sangiorgi, 2018, Teixeira et al., 2017, Storey and Larbig, 2018, Patricio et al., 2018) as well as supporting service innovation (Joly et al., 2019, Vink et al., 2019, Yang and Sung, 2016). This study provides examples of each situation, examining ICT's that used different design principles to support different service strategies. In addition, it considers the issues encountered during the transition between differing systems designs. ICTs improved current services by codifying processes (proposition 1) in Co. A and improving customisation in Co. B (proposition 2 \& 3b). Although all three trajectories involved greater knowledge codification proposition 1 involved systems that followed a different, more rigid, design philosophy to the more dynamics codification in systems related to propositions $2 \& 3$ b. In addition, Co. C was able to create new services from modular components (propositions $3 \mathrm{a}$ and $3 \mathrm{~b}$ ). It should be noted that even among codification of dynamic services the system design in Co. B (proposition 2) was different to the modular design of Co. C's ICT. Nonetheless, all three firms exhibited innovation through their use of ICTs to change their service design approach. In addition, service design gives life to new ideas (Teixeira et al., 2019, Ostrom et al., 2010). This study found some ICTs could increase rigidity (proposition 1) thus reducing the development of new ideas while other ICTs supporting the development of new ideas by providing employees with access to relevant experts (proposition 2) and an array of modular components with which to develop new ideas (proposition 3a).

This paper extends the service design literature by showing how human centred approaches, coordinating customers and employees, (Blomkvist et al., 2010; Mahr et al., 2013; Meroni \& 
Sangiorgi, 2011; Patricio et al., 2018; Storey \& Larbig, 2018; G. Teixeira et al., 2017; Yu \& Sangiorgi, 2018) can be complemented using different ICTs within differing service strategies. The role of assimilating customer knowledge is central to service design (Storey and Larbig, 2018, Trischler et al., 2018, Dietrich et al., 2017). This study, like (Nordin et al., 2011), also involved firms (Co. B, Co. C) that sought better client understanding to develop highly customised solutions. However, unlike much prior research (Edvardsson et al., 2005, Andreu et al., 2010, Shaw et al., 2011) the role of ICTs did not support the co-creation of services. Rather than supporting interaction between service supplier and customer (Payne et al., 2008, Carlborg and Kindstrom, 2014, Gronroos, 2011), ICTs involved limited interaction concurring with previous research (Glushko and Nomorosa 2013, Paluch 2014) that interpersonal interaction was replaced by ICTs, that did not support customer relationship building (Rust and Miu, 2006; Rust and Huang 2014). A possible reason for this is that knowledge asymmetries (Walsh and O'Brien, 2018) may exist with service providers posessing more knowledge about requirements than their clients.

While modularity involves decomposition into elements (Gershenson et al., 2003, Heizer and Render, 2004) there have been few empirical examples of how ICTs achieve this in a service context. One of the key contributions of this research is to provide empirical evidence of such modular ICT use. Using modularity to gain the flexibility and customisation with the cost efficiency possible from standardisation (Rahikka et al., 2011, Pekkarinen and Ulkuniemi, 2008, Schilling, 2000, Bask et al., 2010, Dorbecker and Bohmann, 2013) was identified (Co.

C) when ICTs were used. The modular system examined (Co. C) illustrated a mutually reinforcing interaction between customisation and modular systems whereby service employees drew on reusable standardised modular elements to develop customised solutions (proposition 3a) and subsequently codified those customised solutions in a modular way (proposition $3 b$ ). While the model also proposed that highly codified rigid standardised services become more dynamic and customised through modular ICTs, we could not support that in this study (proposition 4).

Our findings agree with prior studies (Cabigiosu et al., 2015, Davis et al., 2007) that the development of modular systems, using reconfigurable components, allows service firms to exploit their knowledge and about service processes across a number of supplier relations while 
spreading the costs of providing solutions over many customers. Knowledge could be exploited, not just through the standardisation of services (Sundbo, 2002) but by standardising components. It is therefore necessary to consider not just standardisation as relating to an entire service but to consider how components of a service can be standardised to enable subsequent reuse to enable customisation. Not only can services be transferred across clients (Olivia and Kallenberg, 2003), but modular service components can also be transferred. Mixing and matching (Voss and Hsuan 2009) or bundling (Carlborg and Kindstrom 2014) were found to enable standardised components to be reused to create a customised service process.

The model presented in this paper, drawing on the dynamic perspective of KM strategies (Scheepers et al., 2004, Venkitachalam and Willmott, 2013), provides an alternative way of understanding the relationship between standardisation, customisation, and modularity. Rather than seeing modularity as a compromise (Rahikka, Ulkuniemi et al., 2011) it should be considered a natural progression from either standardisation or customisation. The findings add to a growing body of literature on service modularity. When considering services, it is not only important to consider the ICTs employed but to also identify the form that knowledge takes. Neither Co. A or Co. B used complex modular systems but still had challenges codifying tacit knowledge. However, the way in which the knowledge was codified was different depending on whether it referred to standardised or customised services. Co. C showed a more mature position regarding the use of modular systems changing the nature of interaction between customer and provider.

\section{Managerial and Practical Implications}

There are three practical implications from this research. First, the paper highlights the importance of considering the types of knowledge, tacit or explicit, from which their service is derived, particularly in relation to the use of ICT. Second, the paper provides empirical examples of ICT use for standardisation, modularisation, and customisation, allowing information technology managers to consider their future options. Third, the paper allows managers in service firms to identify where their firm is located within the model in order to assess possible trajectories. 
The framework provided allows ICT managers to identify their firms current position in terms of the nature of the underlying knowledge, whether it is rigid or dynamic, and consider the degree to which this service knowledge is currently codified and how they may need to change their underlying systems to keep knowledge management and service strategies aligned. The findings provide service managers with empirical examples of how technology can be leveraged for each service strategy. From a longer-term strategic perspective, the findings (propositions $1 \&$ 2) indicate that the move from standardisation and customisation to a modular strategy is not a compromise but a potential trajectory which may involve intermediate steps. Both trajectories involve knowledge management design principles to enable the codification of tacit knowledge. However, leverage works differently in each case due to the ways the respective ICTs are designed. Systems designed for standardisation codified knowledge processes (proposition 1) which improved efficiency but resulted in rigidity. Such systems would be suited to more established contexts with less change in underlying processes. Additionally, this firm found it difficult to transition from the resultant standardised process design logic to more modular form (proposition 4). While systems in Co. B were developed to increase codification, this was with the objective of improving expert visibility and communication. Such a design was suited to customised services and where the underlying knowledgebase was constantly changing. The modular system in Co. C was designed to codify knowledge into discrete sections as new knowledge solutions were created and required organisational taxonomies to categorise knowledge. Taxonomies provided structure to how employees categorised solutions and required a change in mindsets, requiring them to consider not only how to codify the existing service but to do so in a way that involved re-usable components. Firms considering a modular design need to consider how to categorise their knowledge and provide guidelines on developing and integrating components for employees to enable codification and in seeking to consider the potential of re-using existing components rather than seeking to develop bespoke solutions for service clients.

\section{Limitations and Future Research}

Finally, it is important to highlight a limitation of the study. It is exploratory in nature, and while using three case studies to validate propositions is approriate, this research can be strengthened by future studies. Such future work could usefully explore a number of areas. This study identified different systems were used for different purposes and with different 
outcomes. While service design and servive strategy research would benefit from a more explicit consideration of ICTs and the forms service knowledge can take a natural progression of this work would be for longitudinal studies of firms using modularity or moving from standardisation or customsiation to examine the types of ICTs used and the processes deployed to enable this continual reformulation and any positive or adverse effects. In addition, work is needed to better understand the mechanisms through which service knowledge is decomposed and recombined within modular componets. Although not explicitly examined in this paper an investigation into how an increased reliance on ICTs can change service providers employees' cognitive processes, in particular, to consider how this can enable and constrain design thinking. Increased use of ICTs to codify knowledge was found to increase knowledge asymmetries with more knowledge being possessed by the service provider. Future service design studies should examine how knowledge asymmetries affect the co-creation of new knowledge.

\section{References}

ADLER, P. S. \& KWON, S. W. 2002. Social Capital: Prospects for a New Concept. Academy of Management Review, 27, 17-40.

AKESSON, M. \& EDVARDSSON, B. 2008. Effects of e-government on service design as perceived by employees. Managing Service Quality, 18, 457-478.

ALAVI, M. \& LEIDNER, D. E. 2001. Review: Knowledge Management and Knowledge Management Systems: Conceptual Foundations and Research Issues. MIS Quarterly, 25, 107-136.

ANDREASSEN, T. W., KRISTENSSON, P., LERVIK-OLSEN, L., PARASURAMAN, A., MCCOLL-KENNEDY, J. R., EDVARDSSON, B. \& COLURCIO, M. 2016. Linking service design to value creation and service research. Journalof Service Management, 27, 21-29.

ANDREU, L., SANCHEZ, I. \& MELE, C. 2010. Value co-creation among retailers and consumers: New insights into the furniture market. Journalof Retailing and Consumer Services, 17, 241-250.

ANTONS, D. \& BREIDBACH, C. F. 2018. Big Data, Big Insights? Advancing Service Innovation and Design With Machine Learning. Journalof Service Research, 21, 17-39.

ARAUJO, L. \& SPRING, M. 2010. Complex performance, process modularity and the spatial configuration of production. In: CALDWELL, N. \& HOWARD, M. (eds.) Procuring Complex Performance: Studies in Innovation in Product-service Management. London: Routledge.

AVLONITIS, V. \& HSUAN, J. 2017. Exploring modularity in services:cases from tourism. International Journalof Operations \& Production Management, 37, 771-790.

BALDWIN, C. Y. \& CLARKE, K. B. 1997. Managing in an age of modularity. Harvard Business Review, September-October, 84-93.

BANTAU, G. \& RAYBURN, S. W. 2016. Advanced information technology: transforming service innovation and design. The Service Industries Journal, 36, 699-720.

BARDHAN, I., DEMIRKAN, H., KANNAN, P. K., KAUFFMAN, R. J. \& SOUGSTAD, R. 2010. An Interdisciplinary Perspective on IT Services Management and Service Science. Journal of Management Information Systems, 26, 13-64. 
BARRATT, M., CHOI, T. Y. \& LI, M. 2011. Qualitative case studies in operations management: Trends, research outcomes, and future research implications. Journal of Operations Management, 29, 329-342.

BARRETT, M., CAPPLEMAN, S., SHOIB, G. \& WALSHAM, G. 2004. Learning in Knowledge Communities: Managing Technology and Context. European Management Journal, 22, 1-11.

BASK, A., LIPPONEN, M., RAJAHONKA, M. \& TINNILA, M. 2010. The concept of modularity: diffusion from manufacturing to service production. Journal of Manufacturing Technology Management, 21, 355-375.

BASK, A., LIPPONEN, M., RAJAHONKA, M. \& TINNILA, M. 2011. Framework for modularity and customization: service perspective. Journal of Business \& Industrial Marketing, 26, 306-319.

BENBASAT, I., GOLDSTEIN, D. K. \& MEAD, M. 1987. The Case Research Strategy in Studies of Information Systems. MIS Quarterly, 11, 369-386.

BETTIOL, M., DIMARIA, E. \& GRANDINETTI, R. 2012. Codification and creativity: knowledge management strategies in KIBS. Journalof Knowledge Management, 16, 550-562.

BITNER, M. J., OSTROM, A. L. \& MORGAN, F. N. 2008. Service Blueprinting: A Practical Technique for Service Innovation. California Management Review, 50, 66-94.

BLOMKVIST, J., HOLMLID, S. \& SEFELSTROM, F. 2010. Service design research: yesterday, today and tomorrow. In: STICKDORN, M. \& SCHNEIDER, J. (eds.) This is Service Design Thinking. Amsterdam: BIS Publishers.

BOISOT, M. H. 1998. Knowledge Assets: Securing Competitive Advantage in the Information Economy, New York, Oxford University Press.

BOTTCHER, M. \& KLINGER, S. 2011. Providing a method or composing modular B2B services. Journal of Business \& IndustrialMarketing, 26, 320-331.

BREIDBACH, C. F., KOLB, D. G. \& SRINIVASAN, A. 2012. Connectivity in Service Systems: Does Technology-Enablement Impact the Ability of a Service System to Co-Create Value? Journal of Service Research, 16, 428-441.

BROWN, C. 1999. Horozontal Mechanisms under Differing IS Organisation Contexts. MIS Quarterly, 23, 421-454.

BROWN, J. \& DUGUID, P. 1998. Organizing Knowledge. California Management Review, Special Issue on Knowledge and the Firm, 40, 90-111.

CABIGIOSU, A., CAMPAGNOLA, D., FURLAN, A. \& COSTA, G. 2015. Modularity in KIBS: The Case of Third-Party Logistics Service Providers. Industry and Innovation, 22, 126-146.

CARLBORG, P. \& KINDSTROM, D. 2014. Service process modularization and modular strategies. Journal of Business \& Industrial Marketing, 29, 313-323.

CARLO, L., LYYTINEN, K. \& ROSE, G. 2012. A Knowledge-Based Model of Radical Innovation in Small Software Frims. MIS Quarterly, 36, 865-895.

CHENG, C. C. J. \& SHIU, E. 2016. Examining the link between service modularity and firm performance: A capability perspective. Journalof Service Theory and Practice, 26, 696-720.

COWAN, R., DAVID, P. A. \& FORAY, D. 2000. The Explicit Economics of Knowledge Codification and Tacitness. Industrial and Corporate Change, 9, 211-253.

COWAN, R. \& FORAY, D. 2000. The economics of codificationand the diffusion of knowledge. Industrial and Corporate Change, 6, 595-622.

DARKE, P., SHANKS, G. \& BROADBENT, M. 1998. Successfully completing case study research: combining rigour, relevance and pragmatism. Information systems Journal, 8, 257-272.

DAVENPORT, T. H., JAVANPAA, S. L. \& BEERS, M. C. 1996. Improving Knowledge Work Processes. Sloan Management Review, 53-65.

DAVIS, A., BRADY, T. \& HOBDAY, M. 2007. Organizing for solutions: Systems seller vs. systems integrator. Industrial Marketing Management, 36, 183-193.

DEBLOK, C., MEIJBOOM, B., LUIJKX, K. \& SCHOLS, J. 2013. The human dimension of modular care provision: Opportunities for personalization and customization. International Journal of Production Economics, 142, 16-26. 
DENHERTOG, P. 2000. Knowledge-intensive business services as co-producers of innovation. International Journalof Innovation Management, 4, 491-528.

DIETRICH, T., TRISCHLER, J., SCHUSTER, L. \& RUNDLE-THIELE, S. 2017. Co-designing services with vulnerable consumers. Journal of Service Theory and Practice, 27, 663-688.

DORBECKER, R. \& BOHMANN, T. 2013. The Concept and Effects of Service Modularity- A Literature Review. 46th Hawaii International Conference on System Sciences. Hawaii.

DUBAY, J. W. 2009. Remote service reduces maintenance costs. Applied Automation, 63, 14.

DURAY, R. 2002. Mass customization origins: mass or custom manufacturing? International Journal of Operations \& Production Management, 22, 314-328.

DURAY, R., WARD, P. T., MILLIGAN, G. W. \& BERRY, W. L. 2000. Approaches to mass customisation: configurations and empirical validation. Journalof Operations Management, 18, 605-625.

EDVARDSSON, B., GUSTAFSSON, A. \& ROOS, I. 2005. Service portraits in service research: a critical review. International Journalof Sercice Industry Management, 16, 107-121.

EISENHARDT, K. 1989. Building Theories from Case Study Research. Academyof Management Review, $14,532-550$.

EKSTEDT, E., LUNDIN, R. A., SODERHOLM, A. \& WIRDENIUS, H. 1999. Neo-Industrial Organising: Renewal by action and knowledge formation in a project-intensive economy, London, Routledge.

FOLSTAD, A. \& KVALE, K. 2018. Customer journeys: a systematic literature review. Journal of Service Theory and Practice, 28, 196-227.

FRANDSEN, T. 2017. Evolution of modularity literature: a 25 -year bibliometric analysis. International Journalof Operations \& Production Management, 37, 703-747.

FURRER, O., SUDHARSHAN, D., TSIOTSOU, R. H. \& LIU, B. S. 2016. A framework for innovative service design. The Service Industries Journal, 36, 452-471.

GALLOUJ, F. \& WEINSTEIN, O. 1997. Innovation in Services. Research Policy, 26, 537-556.

GAMMELGAARD, J. \& RITTER, T. 2005. The knowledge retrieval matrix: codification and personification as separate strategies. Journalof Knowledge Management, 9, 133-143.

GERSHENSON, J. K., PRASAD, G. J. \& ZHANG, Y. 2003. Product modularity: definitions and benefits. Journalof Engineering Design, 14, 295-313.

GLUSHKO, R. 2010. Seven Contexts for Service Systems Design. In: MAGLIO, P. P., KIELISZEWSKI, C. A. \& SPOHRER, J. C. (eds.) Handbook of Service Science. New York: Springer.

GLUSHKO, R. J. \& NOMOROSA, K. J. 2013. Substituting Information for Interaction: A Framework for Personalization in Service Encounters and Service Systems. Journal of Service Research, 16, 21-38.

GLUSHKO, R. J. \& TABAS, L. 2009. Designing Service Systems by Bridging the Front Stage and Back Stage. Information Systems and e-Business Management, 7, 407-427.

GOROVAIA, N. \& WINDSPERGER, J. 2013. Determinants of knoweldge transfer strategy in franchising: integrating knowledge-based and relational governance perspectives. The Service Industies Journal, 33, 1117-1134.

GREMLER, D. D. \& GWINNER, K. P. 2000. Customer-Employee Rapport in Service Relationship. Journal of Service Research, 3, 82-104.

GRONROOS, C. 2011. A service perspective on business relationships: The value creation, interaction and marketing interface. industrial Marketing Management, 40, 240-247.

GUPTA, A. D., KUMARKAR, U. S. \& ROELS, G. 2016. The Design of Experiential Services with Acclimation and Memory Decay: Optimal Sequence and Duration. Management Science, 62,1278-1296.

GUSTAFSSON, A., SNYDER, H. \& WITELL, L. 2020. Service Innovation: A New Conceptualization and Path Forward. Journalof Service Research, 23, 111-115.

HAESLI, A. \& BOXALL, P. 2005. When knowledge management meets HR strategy: an exploration of personalization-retention and codification-recruitment configurations. International Journal of Human Resource Management, 16, 1955-1975. 
HANSEN, M. T., NOHRIA, N. \& TIERNEY, T. 1999. What's your Strategy for Managing Knowledge? Harvard Business Review, 106-116.

HAZLETT, S. A., MCADAM, R. \& BEGGS, V. 2008. An exploratory study of knowledge flows: A case study of Public Sector Procurement. Total Quality Management, 19, 57-66.

HEDLUND, G. 1994. A Model of Knowledge Management and the N-Form Corporation. Strategic Management Journal, 15, 73-90.

HEIKKA, E.-L., FRANDSEN, T. \& HSUAN, J. 2018. Matching value propositions with varied customer needs: The role of service modularity. Knowledge and Process Management, 25, 64-73.

HEIZER, J. \& RENDER, B. 2004. Operations Management, Englewoods Cliffs NJ, Prentice-Hall.

HISLOP, D. 2005. Knowledge Management in Organizations: A Critical Introduction, Oxford, Oxford University Press.

HUBERMAN, A. M. \& MILES, M. B. 2002. The qualitative researcher's companion, Thousand Oaks London, Sage Publications.

IACONO, J. C., BROWN, A. P. \& HOLTHAM, C. W. 2011. The use of the Case Study Method in Theory Testing: The Example of Steel in eMarketplaces. The Electronic Journal of Business Research Methods, 9, 57-65.

JACOBS, M., VICKERY, S. K. \& DROGE, C. 2007. The effects of product modularity on competitive performance: Do integration strategies mediate the relationship? International Journal of Operations \& Production Management, 27, 1046-1068.

JAISMUDDIN, S. M., KLEIN, J. H. \& CONNELL, C. 2005. The paradox of using tacit and explicit knowledge: Strategies to face dilemmas. Management Decision, 43, 102-112.

JENSEN, M. C. \& MECKLING, W. H. 1995. Specific and General Knowledge, and Organizational Structure. Knowledge Management and Organizational Design 1996. Newton MA: Butterworth-Heinemann.

JIMES, C. \& LUCARDIE, L. 2003. Reconsidering the tacit-explicit distinction- A move toward functional (tacit) knowledge management. Electronic Journalof Knowledge Management, 1, 23-32.

JOHNSON, M. D. \& SELNES, F. 2004. Customer portfolio management: toward a dynamic theory of exchange relationships. Journalof Marketing, 68, 1-17.

JOLY, M. P., TEIXEIRA, J. G., PATRICIO, L. \& SANGIORGI, D. 2019. Leveraging service design as a multidisciplinary approach to service innovation. Journal of Service Managmenet, 30, 681715.

KANKANHALLI, A., TANUDIDJAJA, F., SUNTANTO, J. \& TAN, B. C. Y. 2003. The Role of IT in Successful Knowledge Management Initiatives. Communications of the ACM, 46, 69-73.

KARPEN, I. O., GENSER, G. \& CALABRETTA, G. 2017. A multilevel consideration of service design conditions: Towards a portfolio of organisational capabilities, interactive practices and individual abilities. Journalof Service Theory and Practice, 27, 384-407.

KOWALKOWSKI, C. \& BREHMER, P.-O. 2008. Technology as a driver for changing customer-provider interfaces: evidence from industrial service production. Management Research News, 31, 746-757.

KRULL, E., SMITH, P. \& GE, G. L. 2012. The internationalization of engineering consulting from a strategy tripod perspective. The Service Industries Journal, 32, 1097-1119.

KUMAR, J. A. \& GANESH, L. S. 2011. Balancing knowledge strategy: codification and personalization during product development. Journal of Knowledge Management, 15, 118-135.

KURTMOLLAIEV, S., FJUK, A., PEDERSEN, P. E., CLATWORTHY, S. \& KVALE, K. 2018. Organizational Transformation Through Service Design: The Institutional Logics Perspective. Journal of Service Research, 21, 59-74.

LAMPEL, J. \& MINTZBERG, H. 1996. Customizing customization. Sloan Management Review, 38, 2130.

LEONARD, D. \& SENSIPER, S. 1998. The Role of Tacit Knowledge in Group Innovation. California Management Review, Special Issue on Knowledge and the Firm, 40, 112-132. 
LEONARDI, P. 2013. When Does Technology Use Enable Network Changes in Organizations? A Comparative Study of Feature Use and Shared Affordances. MIS Quarterly, 37, 749-775.

LIM, C., KIM, M.-J., KIM, K.-H., KIM, K.-J. \& MAGLIO, P. P. 2018. Using data to advance service: managerial issues and theoretical implications from action research. Journal of Service Theory and Practice, 28, 99-128.

LOKKE, A.-K. \& SORENSEN, P. D. 2014. Theory Testing Using Case Studies. The Electronic Journal of Business Research Methods, 12, 66-74.

LOKKEGAARD, M., MORTENSEN, N. H. \& MCALOONE, T. C. 2016. Towards a framework for modular service design synthesis. Research Engineering Design, 27, 237-249.

LORCA, P. \& DEANDRES, J. 2011. Performance and Management Independence in the ERP Implementations in Spain: A Dynamic View. Information Systems Management, 28, 147-164.

LUIJKX, K., DEBLOK, C., SCHOLS, J., MEIJBOOM, B. \& SCHROEDER, R. 2014. Interfaces in service modularity: A typology developed in modular health care provision. Journal of Operations Management, 32, 175-189.

MAGLIO, P. P. \& SPOHRER, J. 2008. Fundamentals of service science. Journal of the Academy of Marketing Science, 36, 18-20.

MAGNER, B. 2009. Touchpoint. Journalof Service Design, 1, 20-29.

MAHR, D., KALOGERAS, N. \& ODEKERKEN, G. 2013. A service science approach for improving healthy food experiences. Journal of Service Research, 24, 435-471.

MERONI, A. \& SANGIORGI, D. (eds.) 2011. Design for Services, Surrey: Gower.

MEYER, M. \& DETORE, A. 2001. Perspective: creating a platform-based aproach for developing new services. The Journalof Product Innovation Management, 18, 188-204.

MIOZZO, M. \& GRIMSHAW, D. 2005. Modularity and innovation in knowledge-intensive business services: IT outsourcing in Germany and the UK. Research Policy, 34, 1419-1439.

MITHAS, S. \& WHITAKER, J. W. 2007. Is the World Flat or Spiky? Information Intensity, Skills, and Global Service Disaggregration. Information Systems Research, 18, 237-259.

MONNOYER, M. C. 2003. The RESER servey of service literature, 1996-2001: new information and communication technologies and services. A synthesis from eight national reports. The Service Industies Journal, 23,195-221.

MUKHERJI, S. 2005. Strategy in Software Services Organisations: Straddling Codification and Personalisation. IIMB Management Review, 33-39.

MULLER, E. \& DOLOREUX, D. 2008. What we should know about knowledge-intensive business services. Technology in Society, 31, 64-72.

NATTI, S., ULKUNIEMI, P. \& PEKKARINEN, S. 2017. Implementing Modularization in Professional Services- The Influence of Varied Knowledge Environments. Knowledge and Process Management, 24, 125-138.

NISSEN, M. E. 1999. Knowledge-based knowledge management in the reengineering domain. Decision Support Systems, 27, 47-65.

NONAKA, I. 2007. The Knowledge Creating Company. Harvard Business Review, 85, 7-8.

NONAKA, I. \& TAKEUCHI, H. 1995. The Knowledge-Creating Company, New York, Oxford University Press.

NORDIN, F., KINDSTROM, D., KOWALKOWSKI, C. \& REHME, J. 2011. The risks of providing services: Differential risk effects of the service-development strategies of customisation, bundling and range. Journalof Service Management, 22, 390-408.

OLIVIA, R. \& KALLENBERG, R. 2003. Managing the transition from products to services. International Journalof Service Industry Management, 14, 160-172.

OSTROM, A. L., BITNER, M. J., BROWN, S. W., BURKHARD, K. A., GOUL, M., SMITH-DANIELS, V., DEMIRKAN, H. \& RABINOVICH, E. 2010. Moving forward and making a difference: research priorities for the science of service. Journalof Service Research, 13, 4-36.

OSTROM, A. L., PARASURAMAN, A., BOWEN, D. E., PATRICIO, L. \& VOSS, C. A. 2015. Service Research Priorities in a Rapidly Changing Context. Journalof Service Research, 18, 127-159. 
PALUCH, S. 2014. Customer expectations of remote maintenance services in the medical equipment industry. Journalof Service Management, 25, 639-653.

PALUCH, S. \& BLUT, M. 2013. Service Seperation and Customer Satisfaction: Assessing the Service Seperation/Customer Integration Paradox. Journal of Service Research, 16, 415-427.

PAN, S. L. \& SCARBROUGH, H. 1999. Knowledge Management in Practice: An Exploratory Case Study. Technology Analysis \& Strategic Management, 11, 359-374.

PATRICIO, L. \& FISK, R. P. 2013. Creating New Services. In: RUSSELL-BENNETT, R., FISK, R. P. \& HARRIS, L. (eds.) Global Services Marketing Perspectives. Brisbane, Australia: Tilde University Press.

PATRICIO, L., GUSTAFSSON, A. \& FISK, R. 2018. Upframing Service Design and Innovation for Research Impact. Journalof Service Research, 21, 3-16.

PAYNE, A. F., STORBACKA, K. \& FROW, P. 2008. Managing the co-creation of value. Journal of the Academy of Marketing Science, 26, 83-96.

PEKKARINEN, S. \& ULKUNIEMI, P. 2008. Modularity in developing business services by platform approach. The International Journalof Logistics Management, 19, 84-103.

PENA, A. I. P., JAMILENA, D. M. F. \& MOLINA, M. A. R. 2014. Value co-creation via information and communications technology. The Service Industies Journal, 34, 1043-1059.

PETERS, V. J. T., MEIJBOOM, B. R. \& DEVRIES, E. 2018. Interfaces in service modularity: a scoping review. International Journalof Production Research, 56, 6591-6606.

PIEKKARI, R., WELCH, C. \& PAAVILAINEN, E. 2009. The Case Study as Disciplinary Convention: Evidence from International Business Journals. Organizational Research Methods, 12, 567-589.

PINE, J. 1993. Mass customization: The new frontier in business competition, Boston MA, Harvard Business School Press.

POHJOSENPERA, T., KEKKONEN, P., PEKKARINEN, S. \& JUGA, J. 2019. Service modularity in managing healthcare logistics. The International Journalof Logistics Management, 30, 174-194.

POULIS, E., POULIS, K. \& DOOLEY, L. 2013. Information communication technology innovation in a nonhigh technology sector. The Service Industies Journal, 33, 594-608.

PULLMAN, M. E., VERMA, R. \& GOODALE, J. C. 2001. Service Design and Operations Strategy Formulation in Multicultural Markets. Journalof Operations Management, 19, 239-254.

QUI, J. X. J. \& LUI, S. S. 2014. Knowledge role and subunit characteristics in multiunit firms. Journalof General Management, 40, 3-25.

RAHIKKA, E., ULKUNIEMI, P. \& PEKKARINEN, S. 2011. Developing the value perception of the business customer through service modularity. Journal of Business \& Industrial Marketing, 26, 357-367.

RAJAHONKA, M., HUHALA, J.-P., LEMINEN, S., TOLO, M. \& SIHVONEN, A. 2011. Digital Service Offering Modularity: An Empirical Analysis of Traditional Publishing Industry. 1st Cambridge Academic Design Management Conference. Cambridge.

RIEGE, A. \& O'KEEFFE, M. 2007. Intra-Organisational Knowledge Drivers in the INPD Process: The Case of Watty Limited. Journalof International Innovation Management, 11, 349-378.

RITALA, P., HYOTYLA, M., BLOMQVIST, K. \& KOSONEN, M. 2013. Key capabilities in knowledgeintensive service business. The Service Industies Journal, 33, 486-500.

RUST, R. T. \& HUANG, M.-H. 2014. The Service Revolution and the Transformation of Marketing Science. Marketing Science, 33, 206-221.

RUST, R. T. \& MIU, C. 2006. What Academic Research Tells Us About Service. Communications of the $A C M, 49,49-54$.

SAMPSON, S. E. 2012. Visualizing service operations. Journalof Service Research, 15, 182-198.

SAN-MARTIN, H. \& HERRERO, A. 2012. Influence of the user's psychological factors on the online purchase intention in rural tourism: Integrating innovativeness to the UTAUT framework. Tourism Management, 33, 341-350.

SARKER, S. \& LEE, A. S. 2003. Using a case study to test the role of three key social enablers in ERP implementation. Information \& Management, 40, 813-829. 
SCHEEPERS, R., VENKITACHALAM, K. \& GIBBS, M. R. 2004. Knowledge strategy in organizations: refining the model of Hansen, Nohria and Tierney. Journal of Strategic Information Systems, 13, 201-222.

SCHILLING, M. A. 2000. Toward a general modular systems theory and its application to interfirm product modularity. Academy of Management Review, 25, 312-334.

SCHUMANN, J. H., WUNDERLICH, N. V. \& WANGENHEIM, F. V. 2012. Technology Mediation in Service Delivery: A New Typology and an Agenda for Managers and Academics. Technovation, 32, 133143.

SHAW, G., BAILEY, A. \& WILLIAMS, A. 2011. Aspects of service-dominant logic and its implications for tourism management: Examples from the hotel industry. Tourism Management, 32, 207-214.

SHOSTACK, G. L. 1984. Designing services that deliver. Harvard Business Review, 62, 133-139.

SILANDER, K., TORKKI, P., LILLRANK, P., PELTOKORPI, A., BRAX, S. A. \& KAILA, M. 2017. Modularizing specialized hospital services Constraining characteristics, enabling activities andoutcomes. International Journalof Operations \& Production Management, 37, 791-818.

SONG, S., NERUR, S. \& TENG, J. T. C. 2008. Understanding the Influence of Network Positions and Knoweldge Processing Styles. Communications of the ACM, 51, 123-126.

SORENSEN, C. \& KAKIHARA, M. 2002. Knowledge Discourses and Interaction Technology. Working Paper 115, June 2002. Department of Information Systems: London School of Economics and Political Science, 1-15.

SPENDER, J. C. 1996. Making Knowledge the Basis of a Dynamic Theory of the Firm. Strategic Management Journal (Winter Special Issue), 17, 45-62.

STAKE, R. E. 2000. Case Studies. In: DENZIN, N. K. \& LINCOLN, Y. S. (eds.) Handbook of Qualitative Research. Thousand Oaks: Sage.

STANKEVICIUTE, J. Different Epistemological Perspectives and their Implications for Knowledge Management in Organizations. European Conference on Knowledge Management, $2001 \mathrm{Bled}$ Slovenia. 631-646.

STOREY, C. \& LARBIG, C. 2018. Absorbing Customer Knowledge: How Customer Involvement Enables Service Design Success. Journalof Service Research, 21, 101-118.

SUDBURY-RILEY, L., HUNTER-JONES, P., AL-ABDIN, A., LEVIN, D. \& NARAINE, M. V. 2020. The Trajectory Touchpoint Technique:A Deep Dive Methodology for Servicelnnovation. Journal of Service Research, 23, 229-251.

SUNDBO, J. 1994. Modulization of service production and a thesis of convergence between service and manufacturing organisations. Scandanavian Journal of Management, 10, 245-266.

SUNDBO, J. 1997. Management of innovation in services. The Services Industries Journal, 17, 432-455.

SUNDBO, J. 2002. The service economy: standardization or customization? The Services Industries Journal, 22, 93-116.

TEIXEIRA, G., PATRICIO, L., HUANG, K.-H., FISK, R. P., NOBREGA, L. \& CONSTANTINE, L. 2017. The MINDS method: integrating management and interaction design perspectives for service design. Journalof Service Research, 20, 240-258.

TEIXEIRA, J., PATRICIO, L., NUNES, N. J., NOBREGA, L., FISK, R. P. \& CONSIDINE, L. 2012. Customer experience modeling: from customer experience to service design. Journal of Service Management, 23, 362-376.

TEIXEIRA, J. G., PATRICIO, L. \& TUUNANEN, T. 2019. Advancing service design research with design science research. Journalof Service Managmenet, 30, 677-592.

TRISCHLER, J., PERVAN, S. J., KELLY, S. J. \& SCOTT, D. R. 2018. The Value of Codesign: The Effect of Customer Involvement in Service Design Teams. Journalof Service Research, 21, 75-100.

TURNER, N., MAYLOR, H., LEE-KELLEY, L., BRADY, T., KUTSCH, E. \& CARVER, S. 2014. Ambidexterity and Knowledge Strategy in Major Projects: A Framework and Illustrative Case Study. Project Management Journal, 45, 44-55.

TUUNANEN, T. \& CASSAB, H. 2011. Service Process Modularization: Reuse Versus Variation in Service Extensions. Journalof Service Research, 14, 340-354. 
ULAGA, W. \& REINARTZ, W. J. 2001. Hybrid offerings: how manufacturing firms combine goods and services sucessfully. Journalof Marketing, 75, 5-23.

VARGO, S. \& LUSCH, R. 2008. Service-dominant logic: continuing the evolution. Journal ofthe Academy of Marketing Science, 36, 1-10.

VENCE, X. \& TRIGO, A. 2009. Diversity of Innovation patterns in services. The Services Industries Journal, 29, 1635-1657.

VENKITACHALAM, K. \& BUSCH, P. 2012. Tacit knowledge: review and possible research directions. Journalof Knowledge Management, 16, 357-372.

VENKITACHALAM, K. \& WILLMOTT, H. 2013. Factors shaping organizational dynamics in strategic knowledge management. Knowledge Management Research and Practice, 13, 1-16.

VENKITACHALAM, K. \& WILLMOTT, H. 2017. Strategic knowledge management- Insights and pitfalls. International Journalof Information Management, 37, 313-316.

VICTORINO, L., VERMA, R., BONNER, B. L. \& WARDELL, D. G. 2012. Can Customers Detect Script Usage in Service Encounters? An Experimental Video Analysis. Journal of Service Research, 15, 390400.

VINK, J., EDVARDSSON, B., WETTER-EDMAN, K. \& TRONVOLL, B. 2019. Reshaping mental modelsenabling innovation through service design. Journalof Service Management, 30, 75-104.

VOSS, C. A. \& HSUAN, J. 2009. Service architecture and modularity. Decision Sciences, 40, 541-569.

WALSH, J. N. 2014. The sharing and transfer of context specific knowledge in a product support environment. International Journalof Knowledge-Based Development, 5, 80-97.

WALSH, J. N. \& LANNON, J. In Press. Dynamic knowledge management strategy development in international non-governmental organisations. Knowledge Management Research and Practice.

WALSH, J. N. \& O'BRIEN, J. 2018. Knowledge Asymmetries and Service Management: Three Case Studies. Journalof Information\& Knowledge Management, 17.

WALSHAM, G. 1995. Interpretive case studies in IS research: nature and method. European Journal of Information Systems, 4, 74-81.

YANG, C. \& SUNG, T. 2016. Service design for social innovation through participatory action research. International Journalof Design, 10, 21-36.

YIN, R. K. 2002. Case Study Research: Design and Methods, London, Sage Publications Inc.

YU, E. \& SANGIORGI, S. 2018. Service design as an approach to implement the value cocreation perspective in new service development. Journal of Service Research, 21, 40-58.

ZACK, M. H. 1999. Managing Codified Knowledge. Sloan Management Review, 45-57.

ZOMERDIJK, L. G. \& VOSS, C. A. 2010. Service Design for Experience-Centric Services. Journal of Service Research, 13, 67-82. 
Table 1: Summary of Cases Selected

\begin{tabular}{|c|c|c|c|c|c|l|}
\hline Company & $\begin{array}{c}\text { Number of } \\
\text { Employees }\end{array}$ & $\begin{array}{c}\text { Industry } \\
\text { Sector }\end{array}$ & $\begin{array}{c}\text { Number of } \\
\text { Interviews }\end{array}$ & Observations & $\begin{array}{c}\text { Document } \\
\text { Analysis }\end{array}$ & $\begin{array}{l}\text { Initial Service } \\
\text { Process } \\
\text { Orientation }\end{array}$ \\
\hline A & 550 & $\begin{array}{c}\text { Medical } \\
\text { Device }\end{array}$ & 14 & 2 Years & Yes & $\begin{array}{l}\text { High Tacit, } \\
\text { Low } \\
\text { Codification, } \\
\text { Rigid } \\
\text { Standardisation } \\
\text { - }\end{array}$ \\
\hline B & 6,000 & $\begin{array}{c}\text { Medical } \\
\text { Device }\end{array}$ & 22 & 2 Years & Yes & $\begin{array}{l}\text { High Tacit, } \\
\text { Low } \\
\text { Codification, } \\
\text { Dynamic } \\
\text { Customisation }\end{array}$ \\
\hline C & 26,000 & ICT & 23 & 2 Years & Yes & $\begin{array}{l}\text { High Tacit, } \\
\text { High } \\
\text { Codification, } \\
\text { High } \\
\text { Modularity }\end{array}$ \\
\hline
\end{tabular}

Table 2: Participant Selection

\begin{tabular}{|l|c|c|c|}
\hline Position Within Organisation & Case A & Case B & Case C \\
\hline Manager & 4 & 2 & 3 \\
\hline Team Lead & 2 & 6 & 3 \\
\hline Experienced "Knowledge Workers" & 13 & 4 & 12 \\
\hline Novice "Knowledge Workers" & 3 & 2 & 5 \\
\hline Total (59) & 22 & 14 & 23 \\
\hline
\end{tabular}

Table 3: Co. B. Process Standardisation.

\begin{tabular}{|l|l|}
\hline Process element & Description \\
\hline Procedure Name & Outlines what must take place in the service process. \\
\hline Schematics & $\begin{array}{l}\text { Where the service relates to physical products this element } \\
\text { provides diagrams, pictures and sketches required }\end{array}$ \\
\hline Service Procedure & $\begin{array}{l}\text { A numbered list describing the actions to be taken to } \\
\text { provide the service. }\end{array}$ \\
\hline
\end{tabular}


Table 4: Sections of a Modular Repository Solution

\begin{tabular}{|l|l|}
\hline Section & Description \\
\hline Goals & The actions performed and documented in the fix. \\
\hline Environment & $\begin{array}{l}\text { Clients configuration using terms in the 'environment tree' to } \\
\text { specify the case context. }\end{array}$ \\
\hline Symptoms & $\begin{array}{l}\text { Describe problem characteristics and are objective statements } \\
\text { detailing occurrences. }\end{array}$ \\
\hline Changes & Changes instituted or attempted by the client. \\
\hline Cause & Links symptoms (effects) to actions (changes). \\
\hline Fix & $\begin{array}{l}\text { Outlines the procedure to follow and involves explicitly } \\
\text { documenting the sequence of actions taken. }\end{array}$ \\
\hline
\end{tabular}

Table 5: Model Support

\begin{tabular}{|l|l|l|l|}
\hline Proposition & Case & ICT & Support \\
\hline Proposition 1 & Co. A & UPK & Supported \\
\hline Proposition 2 & Co. B & $\begin{array}{l}\text { Talent } \\
\text { Navigator/Link }\end{array}$ & Supported \\
\hline Proposition 3a & Co. C & Primus & Supported \\
\hline Proposition 3b & Co. B & Agile & Supported \\
\hline Proposition 4 & Co. A & UPK & Not-Supported \\
\hline
\end{tabular}




\section{Figure 1: Proposed Framework}

Explicit

(Codified using ICT)

Tacit

(Not-Codified using ICT)
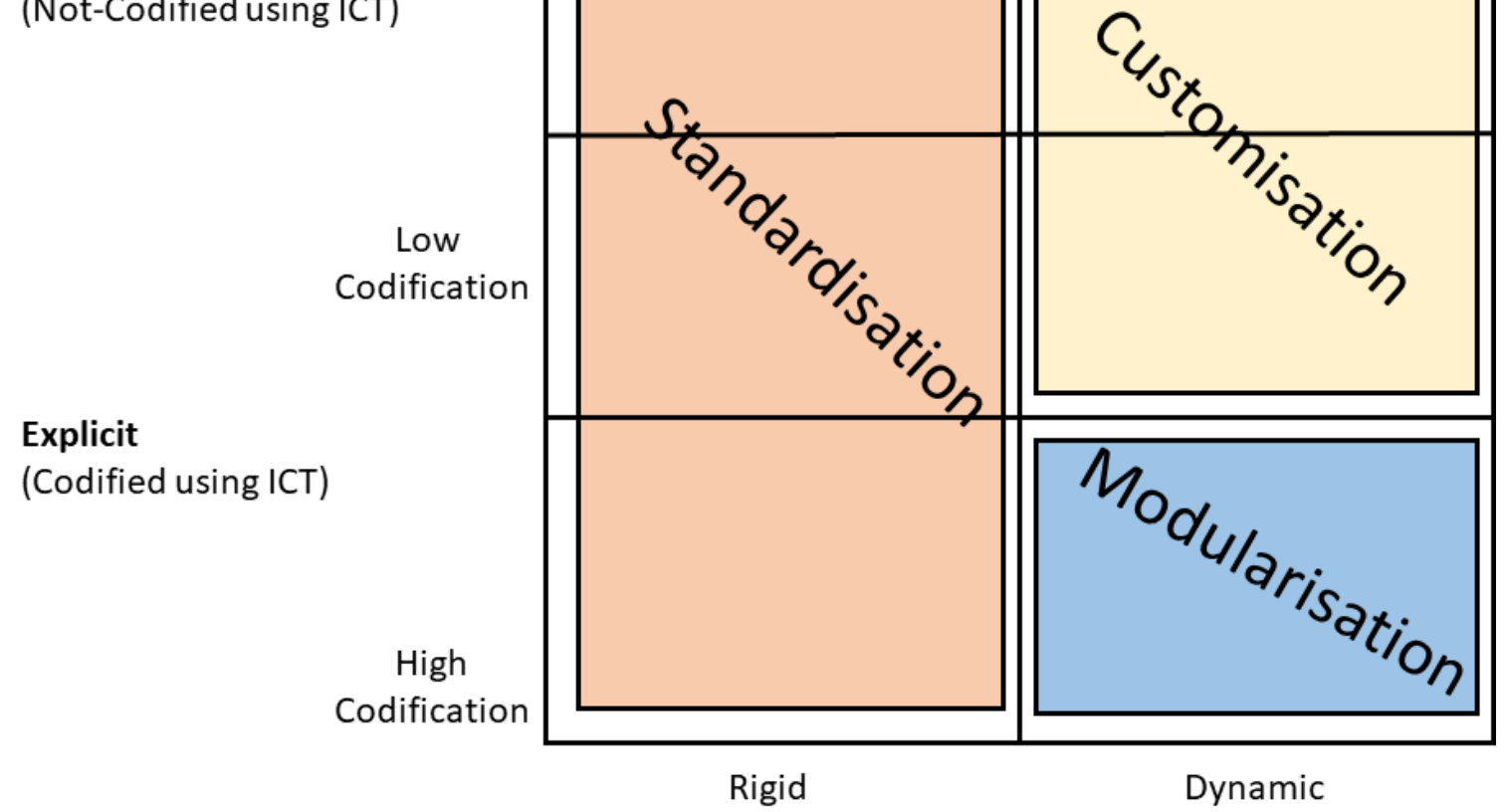

Service Process Orientation

\section{Figure 2: Framework Propositions}

\section{Tacit}

(Not-Codified using ICT)

\section{Explicit}

(Codified using ICT)

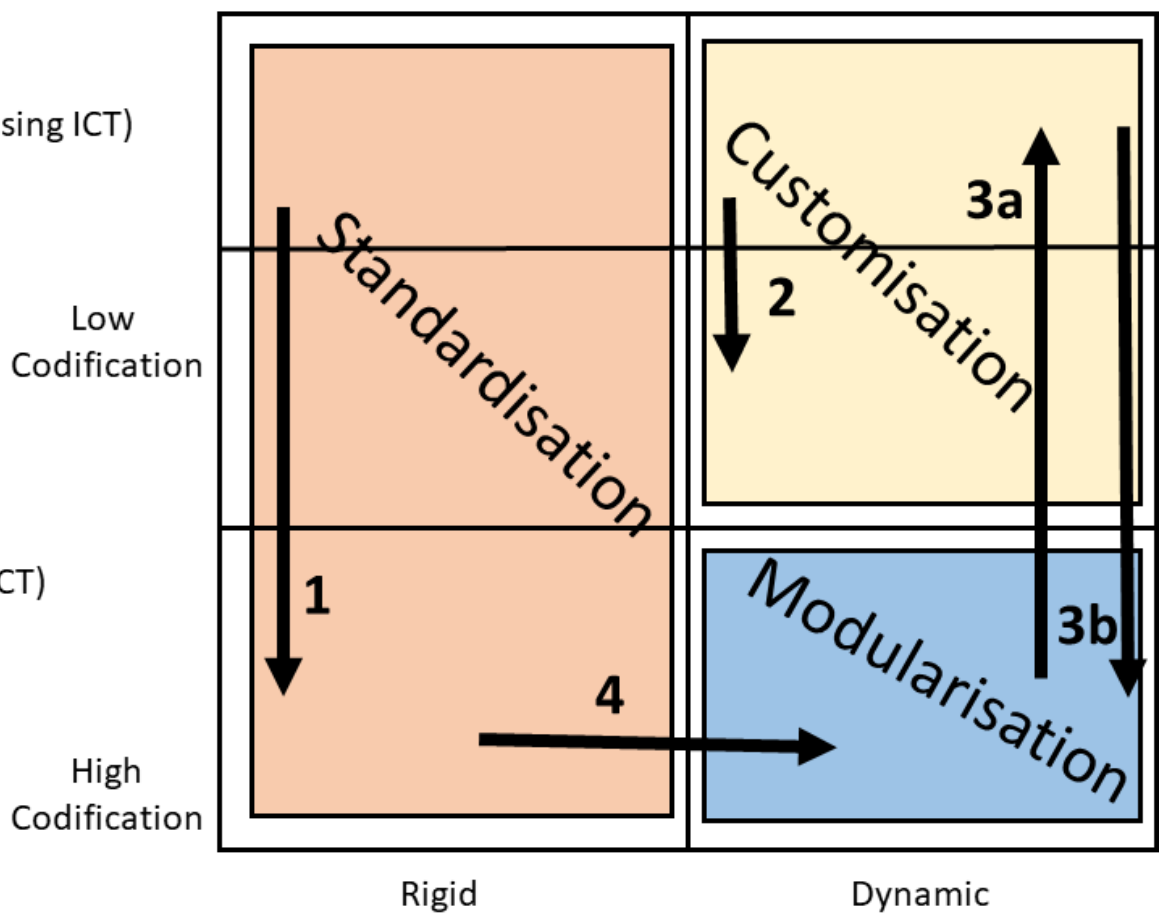

Service Process Orientation 


\section{Figure 3: User Productivity Kit at Co. A}

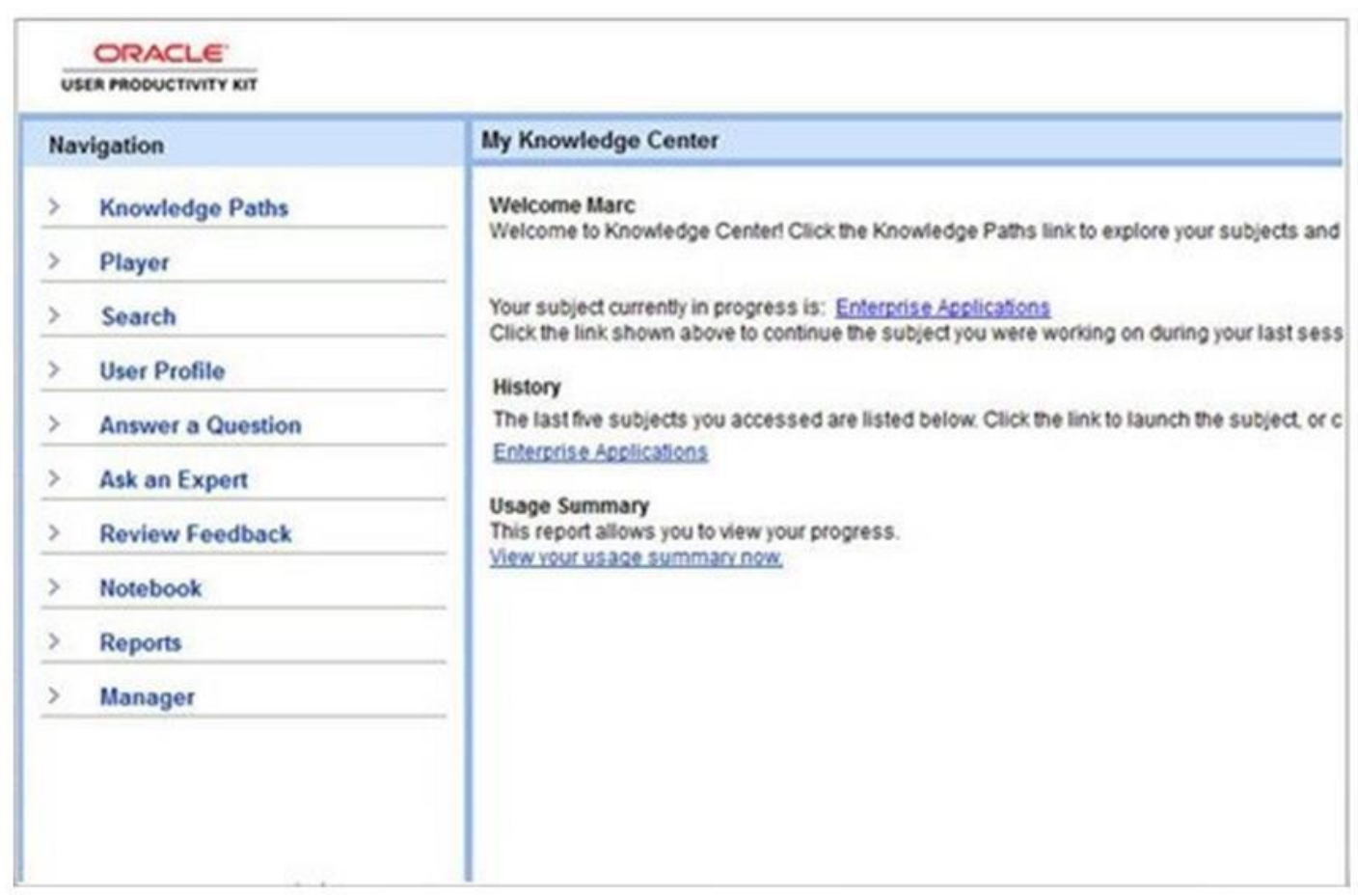

Figure 4: Codification of Standard Services

Tacit

(Not-Codified using ICT)

Explicit

(Codified using ICT)

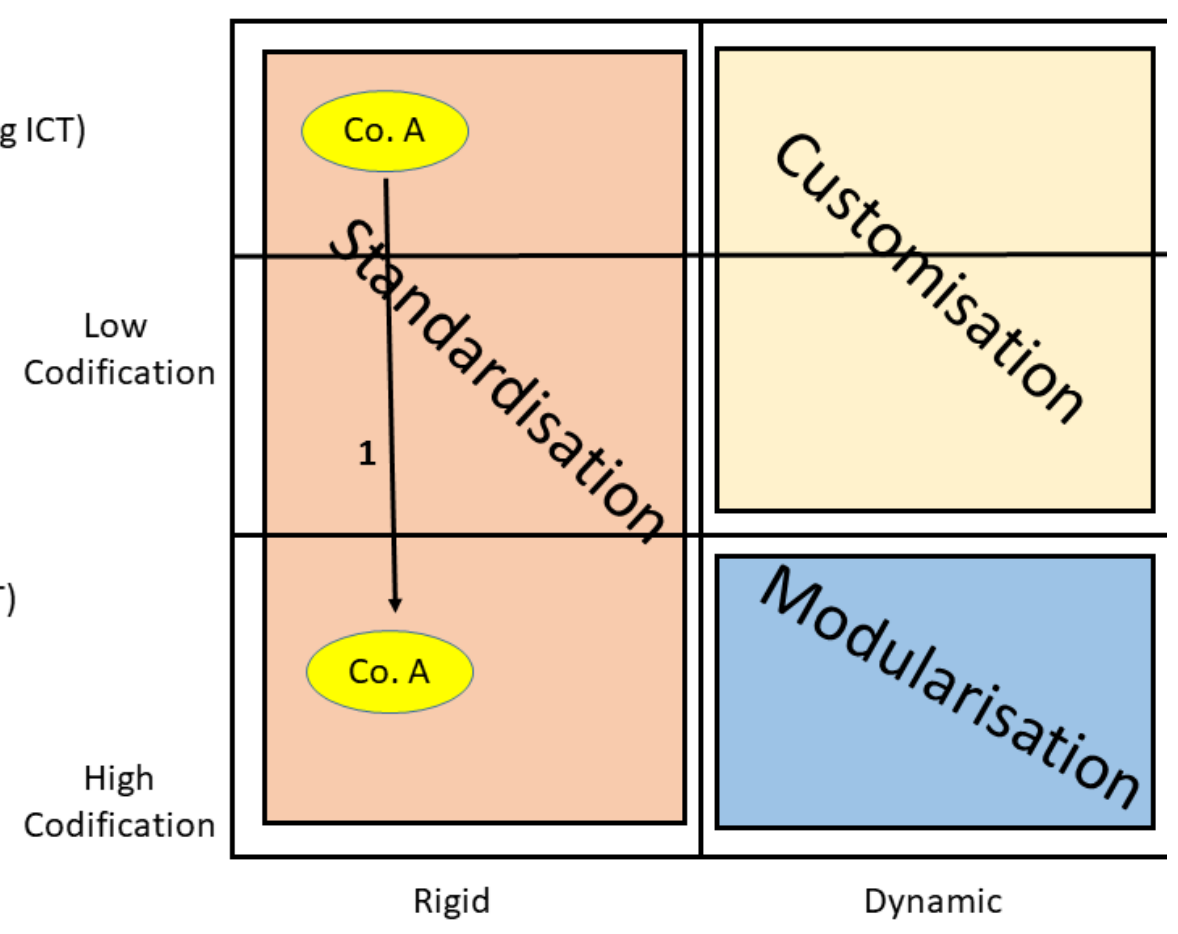

Service Process Orientation 
Figure 5: Talent Navigator
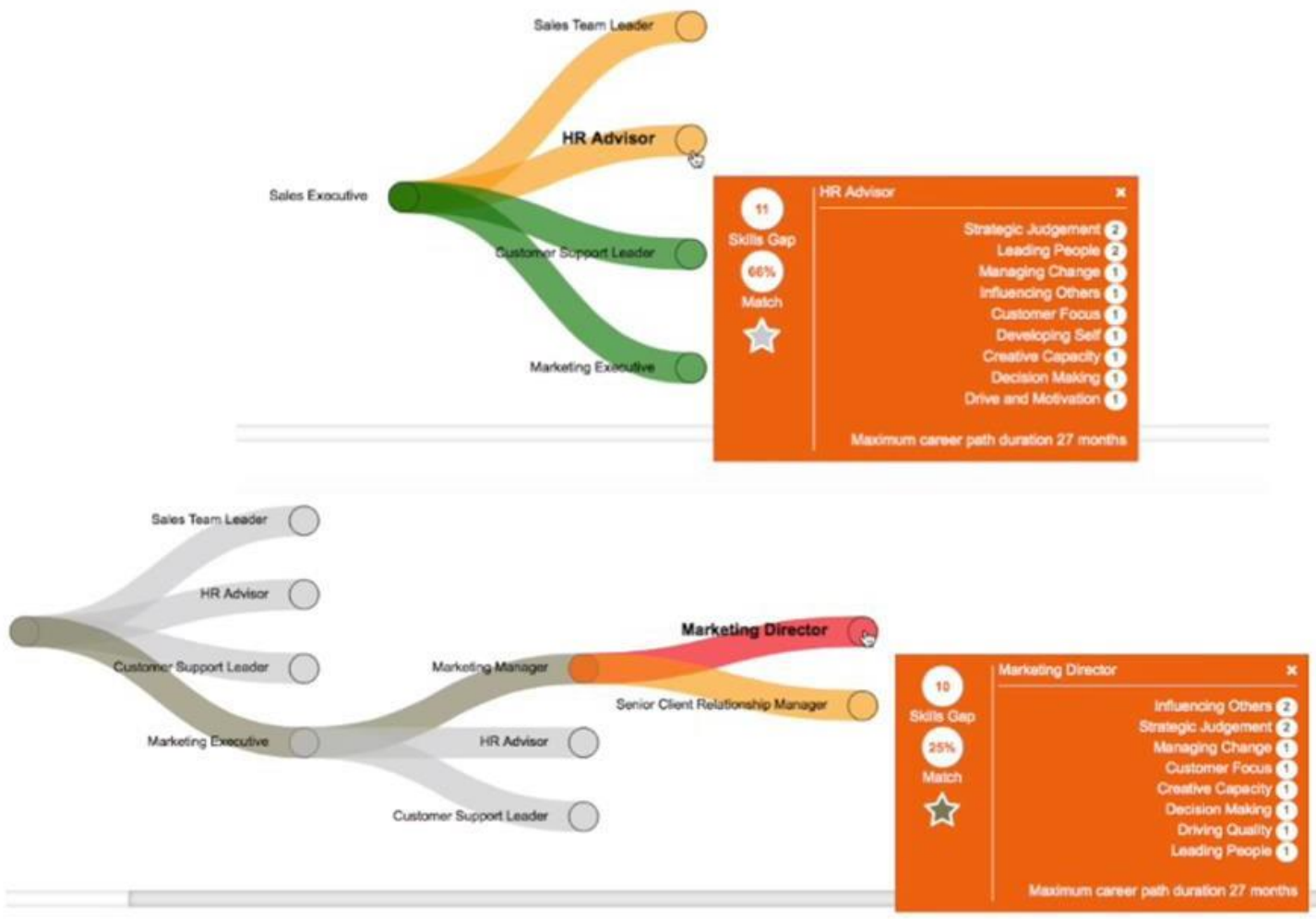

Figure 6: Customised Knowledge Codification

Explicit

(Codified using ICT)

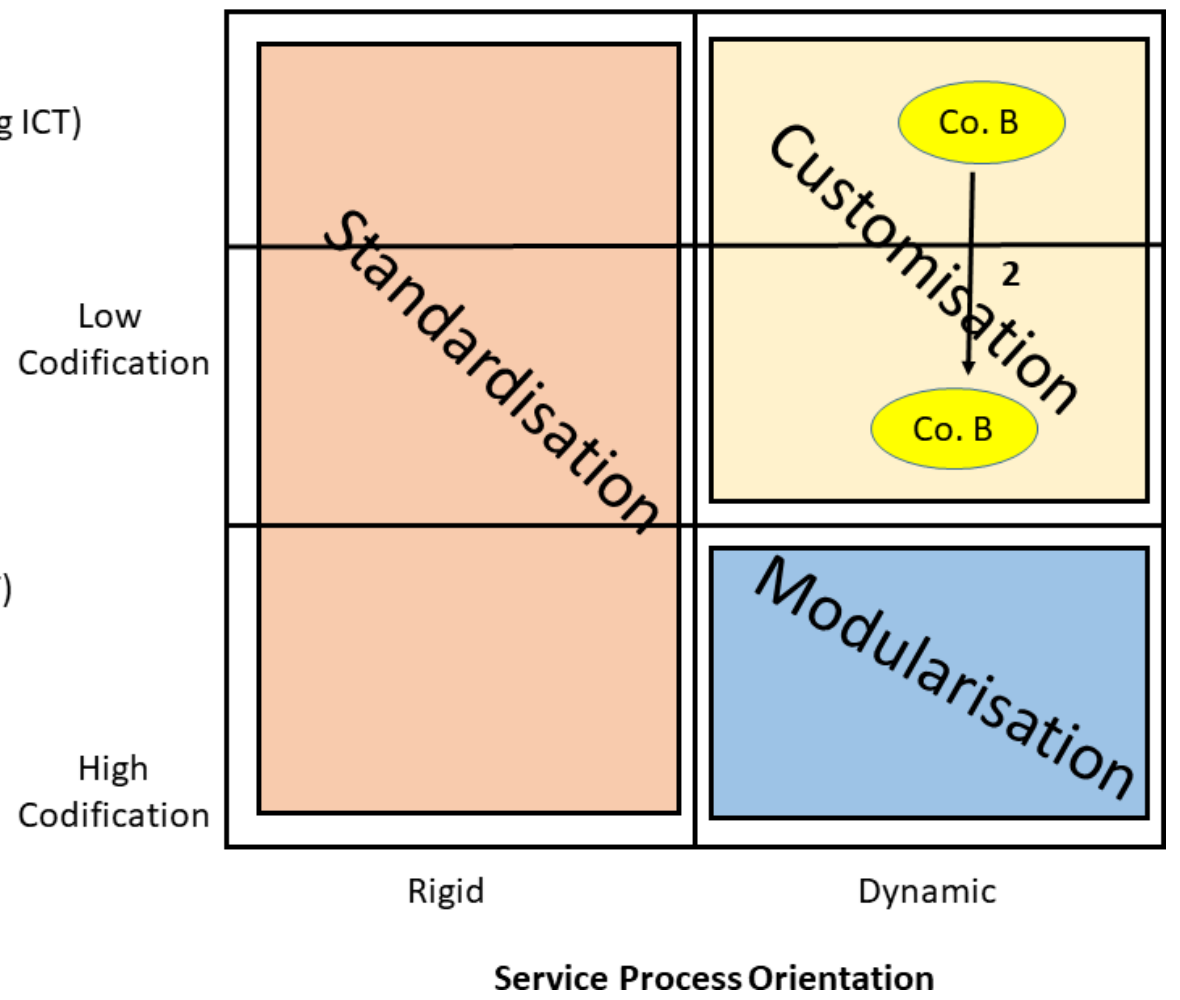




\section{Figure 7: Agile System}

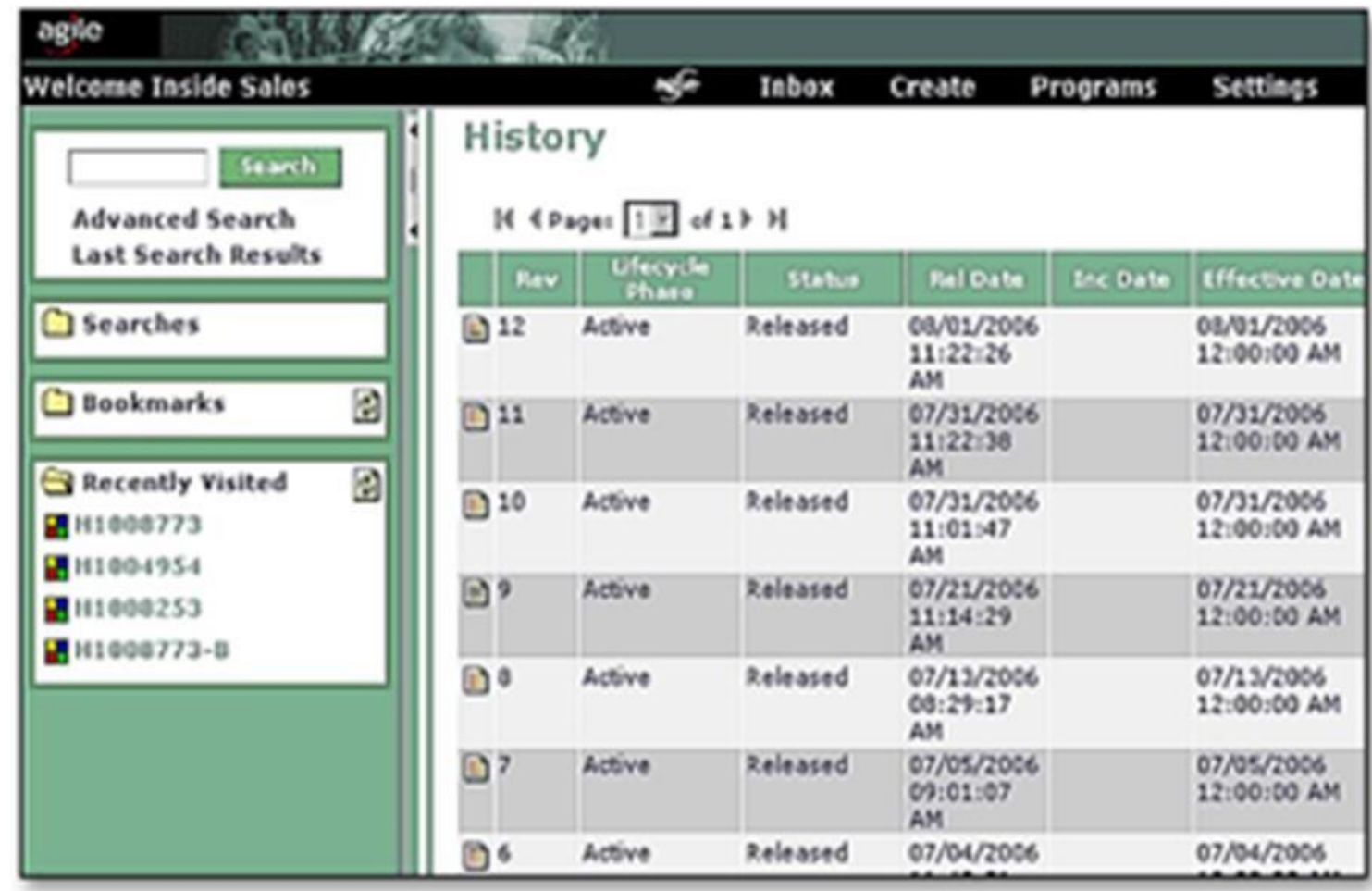

\section{Figure 8: Codification of Customised Modular Knowledge}

Explicit

(Codified using ICT)

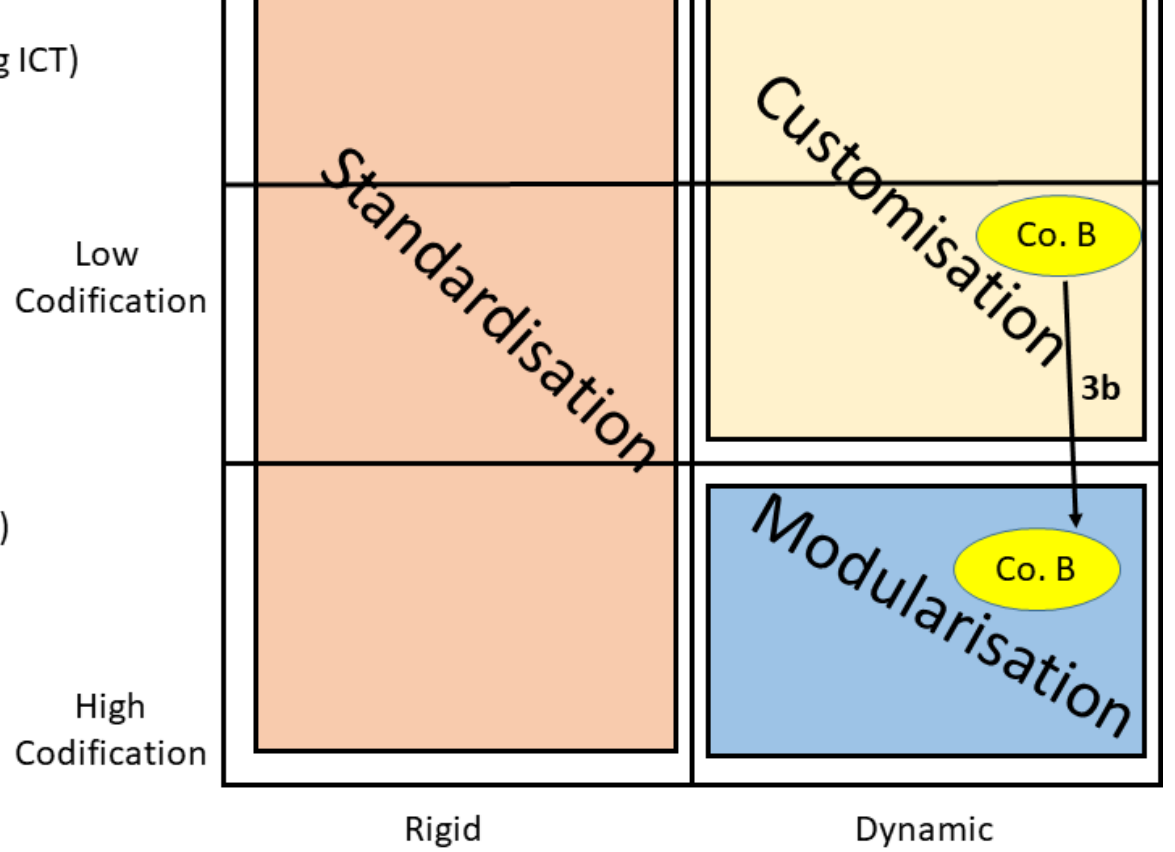

Service Process Orientation 


\section{Figure 9: Customisation-Modularisation Duality}

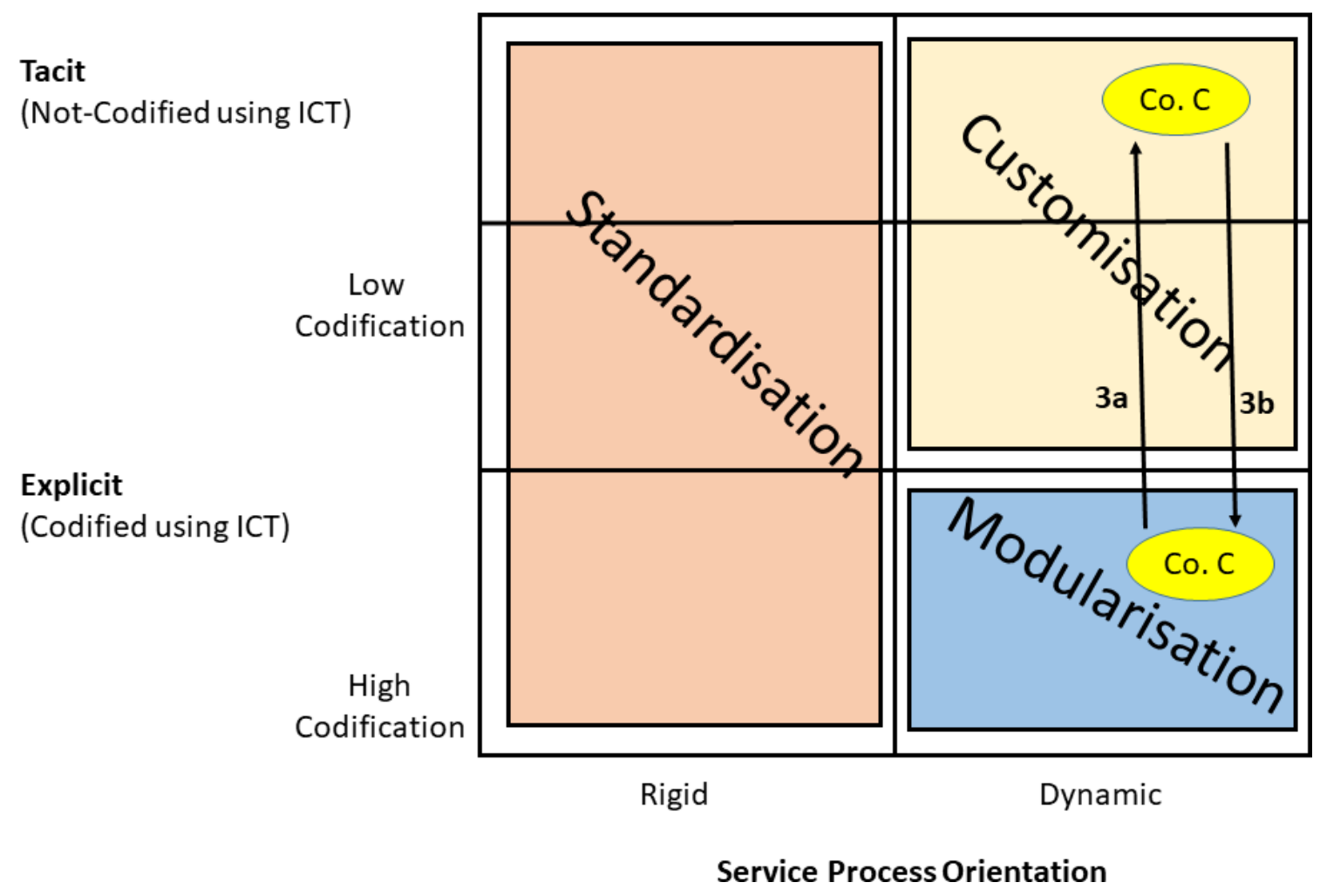

\section{Figure 10: Standardised to Modular Knowledge}

Explicit

(Codified using ICT)

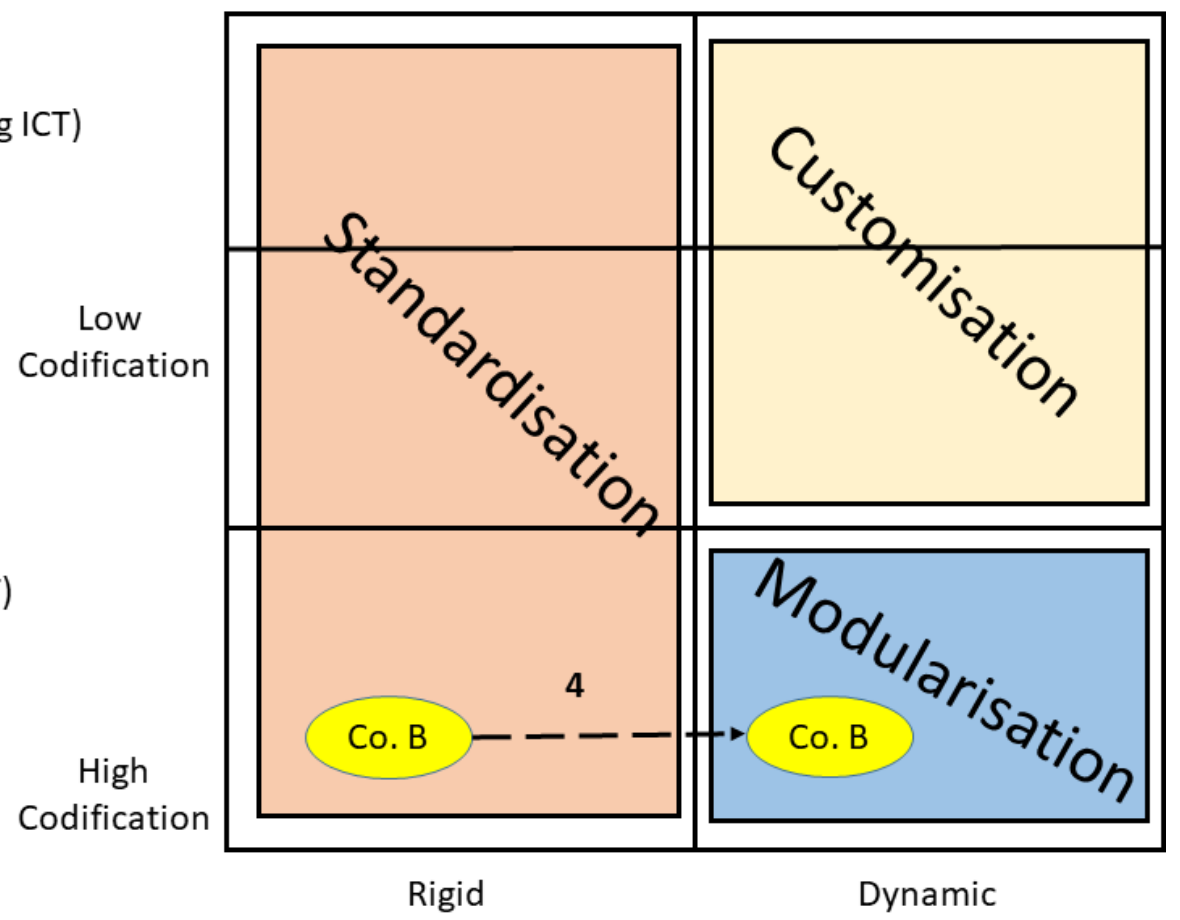

Service Process Orientation 